\title{
NOTAS SOBRE LAS SOLEDADES \\ (A PROPÓSITO DE LA EDICIÓN DE ROBERT JAMMES)
}

Robert Jammes, príncipe de los gongoristas modernos, acaba de publicar una edición monumental de las Soledades ${ }^{1}$, culminación de muchos años de trabajo, — si acaso la palabra "trabajo" (tripalium) le conviene a este luminoso despliegue de agudeza intelectual y de amor a la poesía. La amplia Introducción (pp. 1-157), las innumerables notas y el "Catálogo" final (pp. 607-719) están diciendo una y otra vez que el motor de la empresa ha sido el entusiasmo. Las explicaciones de todo aquello que constituye la multidimensionalidad del lenguaje de Góngora llegan a veces al último extremo de la sutileza y del tecnicismo, pero los comentarios de Jammes están siempre impregnados de admiración por el texto comentado, como cuando, al analizar la comparación del archipiélago de las Molucas con las ninfas de Diana, exclama: "maravillosa metáfora, que evoca, en la luz blanca del amanecer, esa profusión de islas -lejanas y vírgenes-y sugiere, con el mito de Acteón, el gozo casi sensual del descubrimiento"2. ¿Qué bien hace Jammes en no guardar para sí solo estas reacciones!

${ }^{1}$ Luis DE Góngora, Soledades, ed., introd. y notas de Robert Jammes. Castalia, Madrid, 1994; 731 pp. (Clásicos Castalia, 202).

2 Cf. también, entre otras muchas, las notas a I: 385, I: 957 ("larga, espléndida pausa”), II: 163, II: 297 y II: 541 ("soberbia metáfora”). Estos comentarios de Jammes recuerdan el prístino entusiasmo de Francisco del Villar ante el comienzo del poema: "siempre que lo considero me dan impulsos de levantarle estatua"; el de Pedro Díaz de Rivas a propósito de II: 745 ss.: "En este discurso de la cetrería se sobrepuja nuestro poeta a sí mesmo, ansí por ser sobremanera elegante, como por ser argumento que hasta hoy ningún poeta de ninguna lengua ha tocado"; y el de García de Salcedo Coronel a propósito de la descripción del huerto en II: 320 ss.: "[No hay en las Soledades] cosa tan digna de estimación, ni que merezca más justamente el aplauso de todos los ingenios grandes de España", y luego a propósito del verso "las peñas embistió, peña escamada" (II: 443): "No he leído cosa a mi gusto más grande ni que merezca mayor aplauso". 
La Introducción contiene verdaderamente "todo lo que hay que saber acerca de" las Soledades, así en cuanto a sus circunstancias externas como en cuanto a su materia y su forma.

Con "circunstancias externas" me refiero a la historia de la redacción de las dos Soledades (pp. 7-21) y su vinculación con el Duque de Béjar y el Conde de Niebla, los dos grandes señores a quienes Góngora rinde homenaje ("Dedicatoria y dedicatarios", pp. 73-84), así como a la acogida que tuvo el poema a partir de 1613 ("Recepción e impacto", pp. 84-101). A esto último —el colosal estallido de censuras y apologías que fue "la polémica en torno a las Soledades" - dedica Jammes, como es natural, mucho mayor espacio que a lo otro: las 18 páginas que ocupa el asunto en la Introducción se continúan en las 113 finales, donde encontramos noticia puntual de 65 piezas de la polémica, presentadas en orden cronológico ("Catálogo", pp. 607-719). Lleva este "Catálogo" un prologuillo en el cual, después de explicar que estaba destinado a su uso personal - "para no perderme en el maremagnum"-, sin intención de publicarlo, nos dice Jammes por qué cambió de opinión: "[eran] apuntes imperfectos y fragmentarios, pero al redactar las notas al poema, cuando vi cómo se iban multiplicando las referencias a la crítica del siglo XVII, me convencí de la obligación de incluirlos en el mismo libro: era moralmente imposible [pongo esto en cursiva] abandonar al lector inexperto en la tormenta de estas contiendas... sin poner a su disposición una «aguja de navegar gongoristas» que le ayudara a sortear escollos para llegar a puerto". Estoy seguro de que todos los lectores — no sólo los inexpertos- quedamos moralmente obligados con Jammes por habernos hecho el regalo de sus papeletas. Porque, además, se trata de un terreno en que han llovido novedades desde los tiempos de Alfonso Reyes y Dámaso Alonso. La agudeza crítica de Jammes, su bagaje de conocimientos, su sensatez, lo convertían en el mejor guía posible, en el piloto ideal. Jammes pone muy en relieve la importancia del Antídoto contra la pestilente poesía de las Soledades, y es natural que éste figure no sólo en las pp. 618-621 que se le dedican, sino prácticamente en todo el "Catálogo". Por otra parte, me parece muy digno de atención el caveat que en varios lugares de este "Catálogo" expresa Jammes sobre la paternidad de algunas piezas de la polémica: él cree que ciertas "atribuciones" - a Góngora (pp. 614, 662 y 670-671), a Lope de Vega (pp. 613, 624 y 644), a Quevedo (pp. 676-677) - se han hecho sin la necesaria cautela crítica. (Lo cual no significa negar el interés de esas piezas.) 
En las 52 páginas dedicadas a la "materia" de las Soledades hay, por una parte, precisiones sobre su contenido narrativo (pp. 3543), sobre la personalidad del peregrino (pp. 47-50) y sobre la palabra soledad (pp. 59-64) y, por otra parte, hipótesis o especulaciones sobre lo que contendría aquello que Góngora no escribió ("Las cuatro Soledades", pp. 43-47; "El hipotético desenlace", pp. 50-58) y sobre la "localización" del poema (pp. 65-73): Jammes razona muy convincentemente que el "marco geográfico" de la Sol. II, en contraste con el de la Sol. I, "existe realmente: es la parte de la provincia de Huelva que se sitúa entre Huelva y Niebla, es decir la cuenca del río Tinto (aunque podría ser la del Odiel) y el estero en que se reúnen ambos ríos", - del cual hay una foto frente a la p. 65 .

Las 56 páginas dedicadas a la "forma" se inician con unas excelentes consideraciones sobre el lenguaje de las Soledades ("La dificultad gongorina", pp. 102-125). Merece subrayarse lo que dice Jammes sobre el vocabulario "culto" de Góngora. Esa tendencia suya "a volver a la raíz latina —o griega- de las palabras [insultar 'acometer', repetir 'dirigirse hacia', etc.], y muchas veces al sentido primitivo que podían tener en aquellas lenguas..., constituye uno de los aspectos más característicos y más modernos del poema" ( $\mathrm{p}$. $108)^{3}$. En cuanto al hipérbaton, tenido comúnmente como el gran culpable de la "oscuridad" del poema, Jammes lo pone en su lugar justo: "El que tenga la paciencia de leer las notas de la presente edición, dedicadas en mayor parte a problemas de interpretación literal, podrá comprobar que no hay un solo caso, no digo de «oscuridad», sino de dificultad verdadera..., debido a un hipérbaton. Todos proceden de otras causas" (p. 114). Estas otras causas son la alusión ("la historia de los descubrimientos y conquistas, por ejemplo, está relatada... sin que aparezca un solo nombre de persona o de lugar - proeza y, sin duda, súmmum de la técnica alusiva", p. 119) y el conceptismo. "Es curioso — dice Jammes- que la crítica se haya empeñado durante más de tres siglos en hacer del «cultismo»... la marca por excelencia de la poesía de Góngora"; y en seguida: "Todavía más curiosa — y más lamentable— es la oposición [entre cultismo y conceptismo]. Esta dicotomía, generalmen-

${ }^{3}$ A continuación añade: "Ahondando un poco, es posible discernir una correspondencia entre esta vuelta a una lengua primitiva y el ideal de las Soledades: un poco como si esta especie de palingenesia del lenguaje, que parece restituirlo a una mítica edad de oro, fuera, en el vocabulario, la realización de los ensueños que inspiran el « $\mathrm{O}$ h bienaventurado / albergue a cualquier hora!»”. Observación que yo encuentro admirable. 
te abandonada ahora, pero cuyos vestigios se disciernen todavía", ha sido un enorme estorbo para la visión crítica. La verdad es que "el mayor "conceptista»... de la poesía española es Góngora" (p. 120). Y esto ya lo había visto Gracián. Los "conceptos", enlazados unos con otros, "forman como una red tupida" y "constituyen indudablemente la mayor dificultad de las Soledades" (p. 123). Complemento de lo anterior son las páginas (125-143) dedicadas a la "función de la retórica": la comparación, la perífrasis y sobre todo el oximoron, que es (aparte de la metáfora) "la [figura retórica] más frecuente en el poema... y la más representativa del conceptismo de Góngora” (p. 135).

"El mejor ejemplo del refinamiento — tan delicado que llega a ser casi imperceptible - con el que Góngora adapta sus recursos estilísticos al tema... se encuentra, a mi juicio, en la versificación" (p. 143). Este aspecto del arte gongorino no ha sido estudiado como Dios manda, pero las observaciones de Jammes son dignas de ser tomadas como punto de partida, pues atañen a lo básico. Lo primero que él observa es "la perfecta continuidad del poema", cuya forma es la silva, metro que es la negación misma de toda partición estrófica. Las ediciones modernas han venido fragmentándolo en "estrofas" más o menos cortas, y con espacios en blanco entre una y otra, lo cual ha contribuido ciertamente "a resolver el problema de la inteligibilidad"; pero — dice Jammes— ya es hora de "preguntarse si se debe mantener esta presentación". ¿Por qué no imprimirlo todo corrido, sin nada que indique división o interrupción en el discurso? Jammes parece haberse inclinado por esta solución radical, pero - cuerdamente, a mi ver- prefirió hacerle una concesión al lector: en los lugares en que hay "una transición importante" decidió "desplazar ligeramente hacia la izquierda el primer verso" de la transición (pero sin meter espacios en blanco). Así, por ejemplo, Jammes presenta los 137 versos del discurso del "político serrano" (I: 366-502) como un solo y largo período, mientras que Millé decidió repartirlos en 13 "estrofas" y D. Alonso en 15.

La otra observación importante de Jammes se refiere a la rima. Por una parte, al completar una cláusula u oración gramatical, Góngora suele dejar "pendiente" (en el aire) un consonante cuya pareja vendrá hacia el comienzo de la cláusula siguiente, de manera que la bisagra de rimas ("encabalgamiento consonántico" dice Jammes) acentúa la "continuidad" del poema. Por otra parte, también suele Góngora poner una gran distancia entre rima y rima, "hasta límites sorprendentes, con intervalos que pueden al- 
canzar diez, doce o catorce versos". Una comparación entre las dos Soledades le permite a Jammes descubrir que esta doble tendencia se fue acentuando en Góngora a medida que avanzaba en la composición del poema. Finalmente, Jammes analiza la evidente finalidad estilística (adecuación al "tema") que en ciertos casos tiene la disposición de las rimas. Lo que aquí dice (pp. 151-154, con la nota 137) me parece el summum de la finura ${ }^{4}$.

En las páginas dedicadas a la versificación no considera Jammes fenómenos prosódicos como la diéresis y la sinéresis, pero se ocupa cumplidamente de ellos en el curso de la anotación del poema. Se me ocurren sobre esto algunas observaciones.

Dice Jammes (p. 619, nota 16) que el Antídoto de Jáuregui censura en la Sol. I veinte casos de diéresis, y comenta doce de ellos a lo largo de las notas: siẗ̈al D: 25, abrevïar 665, apremüar 875 , vïolar 1034 (pero violar 414), impacïente 756, premüados 1024, espacïoso 228 (pero espacioso 718), glorïoso 979 (pero glorioso 422), imperïoso 186, ingenïoso 252, invidïoso 65 (pero invidioso 989) y nervïoso 1039. Al afirmar Jáuregui que "en nuestra poesía no pueden sufrirse" tales alargamientos, lo que hace es exhibir sus muchas ganas de morder. Ciertamente la pronunciación normal hacía diptongo en estas dicciones, pero los poetas solían deshacerlo. Díaz de Rivas adujo el ejemplo de Herrera, amiguísimo de la diéresis. Y es claro que Jáuregui conocía a Garcilaso, que constantemente la usa: odïoso, glorïoso, virtüoso, (des)confianza, enfrïar, varïar, italïano, mantüano, Dïana, vïaje, quïeto, etc. Eliminada su bilis, lo que dice Jáuregui se

${ }^{4}$ A propósito del alejamiento entre rima y rima observa Jammes que la tendencia aparece en las Soledades "mucho más que en las demás silvas con las cuales he podido compararlas" (p. 149). En un artículo reciente, NRFH, 43 (1995), p. 406, digo que este alejamiento entre rimas es uno de los rasgos gongorinos de la versificación del Primero Sueño de Sor Juana. - A las dos "tendencias" senaladas por Jammes podría añadirse una más: en la Sol. $I$ hay ocho tiradas de diez o más versos pareados (119 ss., 164 ss., 223 ss., 319 ss., 458 ss., 688 ss., 702 ss. y 1045 ss.), y en la Sol. II únicamente dos (34-43 y 710-719). Jammes no dice nada sobre un caso como el de I: 163-171, donde en el espacio de nueve versos hay cinco rimas iguales (-ado). Este rasgo gongorino también se encuentra en el Sueño de Sor Juana. (En cuanto a versificación, la única diferencia importante entre el Sueño y las Soledades es que en éstas no hay un solo verso suelto, y en aquél hay hasta una docena.) En comparación con los refinamientos gongorinos (y sorjuaninos), las silvas de Quevedo resultan muy simplonas. Véase, por ejemplo, "Diste crédito a un pino...", donde las rimas se acomodan en grupitos de cuatro (atab, abba) o en pareados. 
reduce a una observación muy justa: es notable la afición de Góngora a las suntüosas diéresis latinizantes. Sintiendo evidentemente que "nuestra poesía" no sólo puede "sufrirlas", sino que se enaltece con ellas, Góngora decidió por ejemplo escribir "de invidïosa bárbara arboleda" 65 y "sublime espacioso llano" 228 donde la primera redacción decía "de la invidiosa bárbara arboleda" y "sublime y espacioso llano"5.

No es difícil seguir el progreso de esta afición. En 1582 había escrito Góngora "por el suelo andaluz tu real camino" (Millé 226), pero en las Soledades mide siempre rëal, en dos sílabas. Y hay un avance de una a otra Soledad: en I: 573 y I: 718 se lee todavía espacioso, pero en II: 107 y II: 194, espacïoso; en I: 460 precioso, pero en II: 779 preciosos. Las diéresis abundan especialmente en la Sol. II (aún no conocida cuando Jáuregui escribió el Antídoto): afectüoso 239, armonïoso 251, concentüoso 182, espongïoso 179, flexüoso 265, ingenïoso 633 y 788, majestüoso 697 (ya en D: 24, sin crítica de Jáuregui), oficïoso 640 , prodigïoso 471, tortüoso 824, abrevïar 811 , continüar 190, invidiar 895, Dïana 420, idïoma 357, tïorba 350, chiprïota 750, inquïeto 716 y 842, inferïor 918 , auxiliar 910 , intüitivo $896 \ldots{ }^{6}$. Y el avance continuará en los años sucesivos. En las Soledades Góngora mide triunfo como bisílabo (I: 157, I: 687, II: 506), pero en 1618 lo hará trisílabo (Millé 74, v. 328); y mide diamante como trisílabo (I: 383, II: 65, II: 93, II: 167), pero en 1620 como tetrasílabo (Millé 357); y también en 1620 dirá "Purpúrëo creced, rayo luciente" que este purpúreo es siempre trisílabo en las Soledades.

En Garcilaso, la sinéresis es tan frecuente como la diéresis. Palabras como río, frío, mío, día, vía y guía, y las formas verbales habia,

${ }^{5}$ Este "cultismo" es un caso más de "palingenesia del lenguaje", de "vuelta a una lengua primitiva", como dice Jammes (cf. supra, nota 3) a propósito de los cultismos en general.

${ }^{6}$ De hecho, en esta Sol. II son raros los casos — ambicioso 76, gracioso 283, ocioso 837 y 971, agraviar 338, nupcial 31 y 608- en que Góngora se abstiene de hacer diéresis. Es notable la vacilación entre vïol y viol: vïolador 462, pero inviolable 313, violado 428, violencia 23 y 491 (recuérdese la "vïolencia infinita" del Polifemo, y el comentario de D. Alonso). La misma vacilación había ya en la Sol. I: vïolar 1034, pero violaron 414 y violentando 1007.

${ }^{7}$ No es aceptable el texto que da el ms. Chacón: "Purpureo creced rayo lucíènte", o sea lucïente. La diéresis supone siempre un "regreso" al latín (odïoso $<$ oď̌osus, etc.). Esto se aplica a impaciente (<impatientem), como se lee en I: 756 y en el soneto "Prisión del nácar...", pero no a luciente $(<$ lucentem): ningún poeta dijo dïente $(<$ dentem) ni müeve $(<$ movet). El copista del ms. Chacón, notable calígrafo, se equivoca a veces: escribe purpuréàra (son. "Los rayos que a tu padre..."), insinúàre (son. "Oro no rayó...") y Pháèton (son. "Gallardas plantas..."), pero hay que leer, respectivamente, purpureará, insinuaréy Faetón. 
podía, sería, tenía, debría, etc., casi sistemáticamente sufren sinéresis (excepto, claro, si están en final de verso: "Mi lengua va por do el dolor la guía; / ya yo con mi dolor sin guí camino"), de manera a veces violenta para el oído moderno ("Hermosas ninfas que en el río metidas...", "Pintado el caudaloso río se vía..."). En Góngora, en cambio, los casos de sinéresis son tan raros, que Jammes ha podido ir llamando la atención sobre ellos a lo largo de las notas: podía I: 7, alquería I: 96, había I: 470, rubies I: 786, habían I: 958, mía II: 131, sabía II: 563 y escondía II: 878 . En todos estos casos —salvo en perdían I: 148, que quizá no vio- suprime Jammes el acento e imprime podia, alqueria, etcétera.

Así, pues, Jammes contrapone "gráficamente" diéresis y sinéresis: rüido, con crema, caso de diéresis 8 ; rubies, sin acento, caso de sinéresis. Pero hay, creo yo, una diferencia: mientras que rüido, glorioso, etc. no estorban gran cosa la lectura (además de que el signo gráfico de diéresis ha venido usándose desde el siglo XVIII), el lector que cae sobre "sabia apenas" II: 563 o sobre "alqueria de Flora” I: 96 sí experimenta un pequeño tropiezo, pues naturalmente lee sábia y alquéria. En todo caso, si no perjudiciales, sí son inútiles estas supresiones del acento. Sólo un lector muy novato pronunciaría hipermétricamente, con 12 sílabas, el verso I: 7 al verlo impreso en la forma usual (la de D. Alonso): "cuando el que ministrar podía la copa”. El lector normal, el familiarizado con el endecasílabo, de manera automática hará la sinéresis (y ciertamente no pronunciará pódia, ni siquiera podiá, sino en verdad podía, con una i pequeñita, difícil de describir). Nada más normal en nuestra métrica, desde Garcilaso por lo menos: día es bisílabo en su Soneto XXV, v. 10, pero monosílabo en su Canción III, v. 13; ruido es trisílabo en su Canción III, v. 1, pero bisílabo en su Canción IV, v. 98; casi siempre le da tres sílabas a suave, pero en dos lugares (Égl. II, 15; Égl. III, 74) le da sólo dos. La posibilidad de elegir entre lo uno y lo otro está siempre abierta: son sinéresis que no necesitan rótulo de "licencia poética" para ser lícitas. Góngora dice, según sus conveniencias, "más aún que caduca" II: 201 (dos sílabas) y "mayor aún del que espera" I: 571 (una sílaba); puede darle a la desinencia verbal -ía dos sílabas en "no excedía la oreja" I: 139 y en "que habían con trabajo" I: 336, y una sola en "distin-

8 Se le escaparon algunos: también diáfanos I: 205 y II: 143, istriadas II: 383, peruana II: 66 , viales I: 702 y restituir I: 36 debieran haberse impreso con crema. El restituïdo de II: 935 lleva crema; también debieran llevarla atribuído II: 411 y construídos II: 947. 
guir sabía apenas" II: 563 y en "que el bosque habian fingido" I: 958. Y los lectores ni cuenta nos damos".

En nota a II: 882 se detiene Jammes en el caso especial del verbo fiar. Excepto en este verso y en I: 21 y II: 170 —dice-, Góngora pronuncia fiar con diéresis (y cabe añadir infieles II: 867 y desconfianza II: 977). Las excepciones son en realidad sólo dos, pues en I: 21 hay ciertamente diéresis: la lectura obvia no es "fio, | y su vida a un leño", sino fi|ó y su vida a un leño", igual que en II: 467: "un plomo filó grave". (Por cierto, falta el signo de diéresis en fiándose I: 393.)

También valdrá la pena comentar la nota de Jammes al verso "que cuatro veces había sido ciento" I: 470, del cual dice que "plantea un problema". Yo no veo problema alguno. Jáuregui tiene razón al observar que aquí hay acento en $7^{\mathrm{a}}$, pero no acusa a Góngora de haber hecho un verso de doce sílabas ("que | cua|tro | ve|ces | ha|bí|a | si|do | cien|to"): la sinéresis de había le parecería tan normal como la de habian en "que el bosque habían fingido" I: 958. En realidad, ese acento en $7^{\text {a }}$ (bía) queda atenuado o esfumado por la fuerza de los acentos en $4^{\mathrm{a}}$ (vê) y en $8^{\mathrm{a}}(s \hat{i})$, tal como en "leche que exprimir vio la alba aquel día" I: 147 los acentos en $5^{\mathrm{a}}$ y en $7^{\mathrm{a}}$ (mír, la@ál) quedan "neutralizados" por el acento en $6^{\mathrm{a}}$ (vió). Se puede decir, pues, que el verso I: 470 está acentuado normalmente en $2^{\mathrm{a}}, 4^{\mathrm{a}}$ y $8^{\mathrm{a}}$.

Consideración aparte merecen los casos de diéresis/sinéresis entre dos vocales "fuertes" 10 . Jammes observa que en Acteón I: 490 hay "sinéresis" (la hay asimismo en Faetón I: 655 y II: 263), pero no observa que sea (o sean) se pronuncia con una sílaba en II: 133 y II: 164, y con dos en I: 898 y I: 901. ¿Valdría la pena imprimir sëa(n) en los dos segundos casos? ¿Valdría la pena imprimir tëa I: 653 para distinguirlo de tea II: 608, y lëona II: 768 para distinguirlo de leopardo I: 1015? Jammes pone crema en gëometría II: 670, pero no en ge lómetra II: 381; y en Liëo I: 830, pero no en el Himeneo del verso anterior. (Si hiciera falta el signo gráfico, mejor sería imprimir Lïeo.) Bien pudieran llevar crema purpurear D: 15, lisonjear I: 33,

${ }_{9}^{9}$ De lo que sí nos damos cuenta es del contraste entre Melïona II: 765 y melionesa cuatro versos después, a causa de lo muy vistoso de la diéresis de Meliona. Si Góngora hizo esto, fue porque así le convenía, tal como en I: 1077 le convino decir Junón, a la italiana (Giunone), mientras que en I: 812 había dicho normalmente Juno.

${ }^{10}$ Me extraña que el DRAE no traiga definiciones de vocal fuerte y vocal débil, siendo así que s.v. vocal define vocal abierta, vocal cerrada, etc. La gramática tradicional considera "débiles" la $i$ y la $u$, y "fuertes" la $a$, la $e$ y la $o$. 
blanquear I: 438, boreal II: 906, y dos palabras que se repiten: realy teatro. A Océano le dedica Jammes una nota especial, a propósito del excepcional Océano (con sinéresis) de II: 760. Dice que en seis casos -I: 22, I: 35, I: 405, I: 474, II: 75 y II: 701- Góngora pronuncia Ocëano, y en cuatro — dos seguros, I: 425 y II: 529 , y dos probables, II: 376 y II: 494- lo hace esdrújulo. Yo contaría más bien nueve casos - tres seguros, I: 425, I: 529 y II: 163, y seis sumamente probables, I: 22, I: 35, I: 474, II: 75, II: 376 y II: 494- de Océano esdrújulo, y sólo tres -I: 405, II: 10 y II: 701-de Ocëáno. (Jammes no toma en cuenta II: 10 ni II: 163.) Océano es también esdrújulo en el Panegírico, vv. 400 y 620, y en el soneto "En vez de las Helíades...", v. 12.

Otra crítica del Antídoto — no comentada por Jammes- se refiere al hiato y la sinalefa. Jáuregui encuentra censurable que Góngora diga por una parte "montes de agua y piélagos de montes" I: 44 (de| agua, hiato), y por otra "cuando torrente de armas y de perros" I: 223 (de armas, sinalefa). Despojada de bilis, la observación es exacta: Góngora dice de | agua, pero también de agua II: 426; de | oro I: 295 y también de oro I: 326; dice hija | hoy I: 834 y también isla hoy I: 396; cuya | ala II: 764 y cuya asta II: 449; a | ellas I: 631 y a estas II: 387; cada | hora II: 68 y altera_otra I: 258; de | alas I: 449 y de alto II: 384; torpe | era II: 797 y sonante era II: 350; no | ondas II: 577 y no_oya II: 174; centro | era I: 580 y burgo_eran II: 298; cuerno | es II: 307 y carroes I: 76, Junoes I: 812, etc. Consecuencia de lo cual es que a veces resulta imposible un análisis métrico absolutamente preciso. Jammes lee "Parca_es interïor" II: 611, pero también puede leerse "Parca | es interior". Y el v. I: 20 puede leerse "que a una Libia de | ondas", pero también "que a | una Libia de_ondas".

Otro verso que admite dos lecturas métricas es I: 43: lo normal, para nosotros, es "que hacían desigual, confusamente", pero también puede ser "que | hacían desigual...", pues Góngora aspira por regla general la $h$ de hacer (excepciones, II: 736 y II: 806), lo mismo que la de huir, hilar, hilo, hijo, hoja, hado, haya, humo. Por lo demás, en sus versos alternan hermoso (I: 517, I: 877, II: 668) y $(h)$ ermoso (I: 269, I: 344, I: 728) ${ }^{11}$, hallar (I: 472, II: 964) y (h)allar (D: 30, I: 27, II: 487, II: 511), herir (I: 1043, II: 489) y (h)erir (II: 497).

¿Qué hacer en estos casos? Así como hay manera de señalar gráficamente la diéresis (flexüoso, gëometría, etc.) y la sinéresis (po-

${ }^{11}$ Fray Luis dice "por ver y acrecentar su | hermosura", pero también "y viste de (h) ermosura y luz no usada". Garcilaso aspiraba siempre esta y todas las demás haches etimológicas. 
dia, rubies, etc.), ¿valdría la pena discurrir para la $h$ aspirada un signo especial, por ejemplo h? ¿Imprimir "restitüir le hace a las arenas" I: 36 para evitarle al lector, gracias a los dos signos diacríticos, el peligro de pronunciar como eneasílabo este verso? Son preguntas retóricas, por supuesto. Para explicarle a un estudiante primerizo lo que es diéresis y sinéresis, hiato y sinalefa, sería útil presentarle así unos ejemplos de endecasílabos:

o el Austro brame o la arboleda cruja I: 83

cuando halló de fugitiva plata I: 472

la piedad que en mi I alma ya te hospeda I: 520

que parientas del novio aun más cercanas I: 954

los novios saca: él, de años floreciente I: 757

y premïados gradüadamente I: 1024

desde el guante hasta el hombro a un joven cela II: 794

al oro_intüitivo, invidïado II: 896;

pero a un lector ya más o menos hecho, que ha leído sonetos y tercetos y octavas reales, estos signos no le sirven de nada. Sin necesidad de ayuda encuentra en cada uno de esos versos un endecasílabo impecable ${ }^{12}$.

Hay, en cambio, unos signos gráficos que sí le son utilísimos al lector ordinario de poesía: los de acentuación y de puntuación, que con toda razón se modernizan siempre, aun en ediciones muy "filológicas" de textos del siglo de oro. En cuanto a puntuación, el texto que nos ofrece Jammes me parece casi perfecto: en no pocos lugares es mejor que el de D. Alonso. Y digo “casi perfecto" porque encuentro desacertada la falta de comas antes y después de la conjunción pues en casos como "Dejaron pues las azotadas rocas" II: 686, o como "Entre el confuso pues celoso estruendo" II: 735. Quien lee esto tiende espontáneamente a ligar el pues con lo que sigue: "pues las rocas", "pues celoso"; una fracción de segundo le bastará para ahogar el conato de mala lectura, pero no podrá menos de pensar: ¿por qué no "Dejaron, pues, las azotadas rocas" y "Entre el confuso, pues, celoso estruendo / de los caballos"? El tropiezo habrá sido muy leve, pero sería mejor que ni éste hubiera ${ }^{13}$.

12 En cierto artículo, hace mucho, cité un soneto de Arguijo cuyo verso 2 dice "impia ocasión del fin de tu Siqueo", y, muy cauteloso, le puse acento a impia. Y Raimundo Lida, en carta, me dijo más o menos: “¿Por qué con acento? Téngales más confianza a los lectores". (Hace bien Jammes en imprimir ambrosia II: 728, y no ambrósia.)

${ }^{13}$ Casos de este pues: Sol. I, 182, 335, 602, 939 y 995; Sol. II, 9, 144, 167, 196, 
La edición de Jammes me hace pensar en la de la Divina Commedia por la Società Dantesca, o en la del Quijote por Rodríguez Marín, con esas anotaciones que ocupan muchísimo más espacio que el texto anotado: comentan todo lo comentable y recogen cuanta erudición se ha acumulado a través de los tiempos. Minucias, a veces: tremendous trifles, como dijo Chesterton. Pero la presentación tipográfica de la edición de Jammes es más desahogada, más elegante: la porción de texto - a veces apenas tres versosestá en la página derecha, y el comentario respectivo en la izquierda. Estas páginas izquierdas (las pares), fruto de mucho amor y mucho estudio, son sencillamente admirables. Jammes ha prestado a los lectores de la generación actual —y a los de generaciones venideras - un enorme servicio. Sus anotaciones constituyen una summa de gongorismo. Y es una delicia tener todo el tiempo a la vista los comentarios pertinentes, tan amplios a veces, que se continúan en un apéndice.

Están, ante todo, los pasajes de las versiones primitivas del poema, que nos permiten asomarnos al taller de Góngora. Es bonito abrir el libro en el comienzo de la Sol. I y leer en la página izquierda los retoques que fue haciendo el poeta en el verso 6: primero "zafiros pisa, si no pace estrellas", luego "en dehesas azules pace estrellas", y por último "en campos de zafiro pace estrellas". Así también, dentro de la Sol. I, los versos 73 ss., 309 ss., 709 ss., etc.

293, 346, 686, 735, 795 y 869. Sólo en I: 443 pone Jammes las dos comas: "Tú, Cudicia, tú, pues, de las profundas..." (y no "pues de las profundas"). - Aprovecho este rincón para hacer un par de observaciones en cuanto a ortografía. Quien compara las páginas del "manuscrito Chacón" fotografiadas en la ed. de Jammes (pp. 17 y 609) con los lugares correspondientes de la edición, inmediatamente puede ver la modernización que se ha hecho: nada de cient, Echo, frexno, tropheo, zaphiro ni Emulacion, i afrenta, sino cien, Eco, fresno, trofeo, zafiro, emulación y afrenta. Por supuesto, hay cosas — robre, lilio, pluvia, fragrante, prora, etc.cuya "modernización" sería delito; pero creo que Jammes es a veces demasiado conservador. ¿Por qué, por ejemplo, imprimir sceptro II: 823, si ni Góngora ni nadie pronunciaba tal cosa? D. Alonso hace bien en imprimir cetro. Lo mismo digo de colunas I: 475 (D. A. columnas), conjugal I: 802 (D. A. conyugal), scena I: 624 y II: 770 (D. A. escena), stigia II: 793 y II: 979 (D. A. estigia). (Noto que el strépitu del ms. Chacón sí lo cambia Jammes en estrépito II: 974.) Sin duda está bien zanefa D: 24 (D. A. cenefa), pero no sé si también bueitre I: 440 y I: 502 (D. A. buitre) y Cudicia I: 403 y 443 (D. A. Codicia). Añado recebir II: 2 y esgremir II: 840 (D. A. recibir y esgrimir). Jammes imprime estranjero I: 46 et passim, pero también extraño II: 273; proprio II: 131 y propio II: 954; estremo II: 475 y extremo II: 114, II: 529; obscuro I: 967 y oscuro I: 683; safiro I: 711 y II: 613, y zafiro I: 6 y I: 313. 
Alguna vez, como en los versos 854-864, no hace Jammes comentario alguno (deja que el lector compare por sí mismo la versión primera con la definitiva); pero otras veces, como en 913-918, anota cuidadosamente el pasaje. Aquí y allá observa cómo el texto corregido suele ser más dificultoso que el primitivo, lo cual se prestó a errores de interpretación de los comentaristas, por ejemplo el cambio del verso 242, o la supresión de los cuatro versos que seguían al 280 y de los seis que seguían al $290^{14}$.

Varios de los cambios que hizo Góngora en la Sol. I se deben, como es sabido, a las críticas que, a petición suya, le hizo el humanista Pedro de Valencia. Desgraciadamente no se conserva la lista de los pasajes censurados, pero hay datos suficientes para averiguar lo que sucedió. Valencia, formado en la lectura de Demetrio Faléreo, Dionisio de Halicarnaso y "Longino", criticó con especial severidad las "alusiones burlescas" y los "juegos del vocablo" que, según él, desdecían de la belleza de las Soledades. Un caso muy claro es el de los vv. 202-208, corregidos por Góngora a causa de la censura del humanista. A la misma causa atribuye Jammes, con toda razón, los cambios hechos en los vv. 99 y 145 . Yo creo que así se explican también la supresión del pasaje que seguía al v. 290 (traviesa alusión a los "cuernos") y los cambios hechos en los actuales vv. 291-296 (despampanante imagen de las gallinas cuya cresta es borla, casi, de la facultad de Medicina). De los cinco versos que había en vez de los actuales 680-686 dice Jammes que tenían "un carácter demasiado chistoso" (y una sintaxis especialmente enredada): también aquí debe de haber mediado una censura de Pedro de Valencia ${ }^{15}$.

${ }^{14}$ En nota a I: 145-147 hay un pequeñísimo error: son sólo dos (145-146) los versos en que quedaron convertidos los cuatro de la versión primitiva. En cambio, la nota a I: 336-337 debiera decir "336-338" (falta el v. 337 de la primera redacción). En I: 571 se da como primera redacción "mayor del aun que espera", lo cual parece errata. Hay dos casos enigmáticos: I: 777 y II: 923.

15 El verso II: 48 decía "bisagra nunca firme, instable puente", cambiado en "vínculo desatado, instable puente" porque el Abad de Rute, otro de los primerísimos lectores, le hizo notar a Góngora que ya en I: 473 había una bisagra. (¡Qué hilar tan delgado!) En la p. 629, a propósito de una segunda carta de Pedro de Valencia, menos conocida que la otra, observa Jammes la "doble" vertiente que se distingue en las reacciones de Valencia y del Abad de Rute: los dos alabaron el poema cuando lo leyeron, pero, en un principio, expresaron también "una serie de reservas, sugiriendo correcciones; luego, ante los ataques que empezaban a menudear [sobre todo los muy sañudos de Jáuregui], callaron sus críticas y tomaron enérgicamente la defensa del poema”. De la primera carta de Valencia se conocen dos versiones (núms. 126 y 126 bis en el epistolario de la ed. Millé). Comparando la una con la otra se ve cómo, en un lapso seguramen- 
En cuanto al Antídoto de Jáuregui, nadie había puesto de relieve su importancia como lo hace Jammes. Cuando comenzó a circular la Sol. I, Jáuregui la leyó con tanta atención como Pedro de Valencia y el Abad de Rute, pero su reacción resulta mucho más interesante, más útil para los gongoristas. En primer lugar, no se le escapa nada: ¡qué cantidad de censuras sobre vocabulario, sobre sintaxis, sobre metáforas, sobre métrica, sobre cuanto hay! En segundo lugar, Jáuregui es un representante eminente del establishment literario, del gusto imperante (el gusto dictado en particular por Lope de Vega), de manera que todas sus minuciosas críticas son significativas: revelan el tamaño del escándalo, la enormidad del choque causado por la novedad de las Soledades. Y, por otra parte, si no se hubiera escrito el Antídoto no tendríamos los varios y utilísimos "anti-Antídotos". Para la tarea esencial del crítico - "recuperar" plenamente el poema, leerlo con ojos de 1615-, Jáuregui es tan útil como Salcedo Coronel y Díaz de Rivas. A propósito de una crítica excesiva de Jáuregui, debida a su lectura errónea del v. 749, dice Jammes: "Error y reacción instructivos, porque nos permiten apreciar... las dificultades que tendrían los primeros lectores de las Soledades", cuando aún no existían los comentarios de Pellicer y de Salcedo. Por supuesto, ya los bandeirantes del gongorismo moderno, A. Reyes y D. Alonso, acudieron a los comentaristas antiguos, pero nadie les había sacado tanto jugo como Jammes ${ }^{16}$.

te muy breve, Valencia se hizo menos severo, más abierto a la novedad de Góngora. En la primera versión dice que son tales las violencias lingüísticas del poema, "que apenas yo le alcanzo a entender en muchas partes"; en la segunda versión, sin dejar de hacer censuras de detalle, tiene grandes elogios para "casi todo el discurso" del largo poema. En la primera versión, entre los ejemplos de prava affectatio, tan censurada por los preceptistas griegos — como el llamar "sepulcros vivos" a los buitres—incluía la expresión "se reía la rosa” (por 'se abría'), metáfora "violenta" según Demetrio Faléreo. Me parece significativo que este ejemplo haya desaparecido en la segunda versión: Valencia debe de haber comprendido que ante una imagen tan bonita (y tan pre-gongorina) no podía hacer suya la condena de Demetrio.

16 Son interesantes, y nada raros, los casos en que un comentarista leyó de una manera y otro de otra. Para mí, por cierto, han sido un grato redescubrimiento los muchos textos de Díaz de Rivas que reproduce Jammes, pues veo que él es quizá el más atinado de los comentaristas antiguos, y ciertamente el más erudito (y el de estilo más gracioso). En el caso del verso "Si mucho poco mapa les despliega" (I: 194), la interpretación de Díaz de Rivas no es aceptable, pero "si se equivocó — dice Jammes con mucha razón-, su error sería interesante, porque nos indicaría que, hasta para los mejores gongoristas del siglo xVII, resultaba ambigua o difícil esta frase". —En su segunda carta hace Pedro de Va- 
En sus notas también están presentes, como es natural, los gongoristas modernos, escrupulosamente citados. Aquí y allá va reconociendo Jammes la ayuda que le han dado L.-P. Thomas, L. Spitzer, B. Alemany y Selfa, E. J. Gates, R. O. Jones, M. Romanos, A. Carreira y muchos otros ${ }^{17}$. (Y, como no podía ser menos, hay asimismo en las notas algunos "palos" contra ciertas tendencias de la crítica o contra ciertos gongoristas modernos, pero están dados en general con muy buena gracia, por ejemplo I: 75 , I: 93 , I: 159 , I: 295, I: 784, I: 872, II: 413 y II: 937.)

Quien ocupa un lugar prominente entre los gongoristas modernos es, desde luego, Dámaso Alonso. No hace falta ponderar lo mucho que él hizo por la resurrección de las Soledades, ni recordar las excelencias del texto editado por él, los muchos pasajes difíciles sobre los cuales arrojó luz, etc., etc. Una buena manera de calibrar la labor de Jammes es, por eso, compararla con la de su gran antecesor. Pues bien, el lector de la nueva edición puede comprobar con sus ojos que no pocas veces Alonso se quedó a medio camino, o se equivocó, o repitió errores de los comentaristas antiguos, de manera que Jammes puede decir llanamente: "No me parece aceptable la interpretación de Salcedo, adoptada por D. Alonso" (quien está pendiente II: 858 no es el peregrino, sino el baharí), o bien: "Parece totalmente equivocada la interpretación de Pellicer, adoptada por D. Alonso" (puntas II: 846 no significa 'alas'). El texto que imprime Jammes es muy superior al que imprimió Alonso (ejemplos: "y el Sol todo los rayos de su pelo" I: 4, no todos los rayos; "su culta lira" II: 355, no "su oculta lira"). En ciertas ocasiones Alonso no captó bien el sentido de las palabras (ejemplos: fortuna I: 63 'tempestad', 'naufragio', no una genérica 'mala fortuna'; pabellón I: 179 'tienda [de campaña]', no 'cama'; arras I: 985 'prenda o señal', no 'premio'; coro II: 720, no 'grupo musical', sino simplemente 'grupo'; el vuelo del Fénix I: 462: no sus 'alas',

lencia una observación muy certera: a Góngora no hay que compararlo con Homero, "sino con Píndaro, el más grandíloco de los Poetas y casi inimitable, que, corriendo tan claro como qualquiera arroyuelo, el raudal de su corriente y su profundidad lo obscurece y casi lo haze inaccessible, y que no se pudiera pasar sin la varca o puente de los escolios antiguos que han quedado sobre él”. Salcedo y los demás comentaristas hicieron con Góngora lo que los escoliastas bizantinos con Píndaro.

${ }^{17}$ Creo necesario hacer constar que, al escribir el presente artículo-reseña, no me he puesto a leer o releer lo que tantos gongoristas modernos han dicho sobre las Soledades. Me atengo a las citas de Jammes, pues su libro, como ya dije, me parece una auténtica summa o catena aurea de erudición gongorina. 
sino precisamente su 'vuelo', su 'trayecto'; el amebeo del "amebeo canto" II: 626 no es un redundante sinónimo de alterno, sino que tiene un significado específico y "técnico"; eral II: 17 no es adjetivo, sino sustantivo; el membrillo del postre I: 880 no es la fruta, sino la 'conserva de membrillos'18; las conchas de II: 383 no son las del Mar Rojo, que además no tienen estrías, sino "las que se encuentran en las costas europeas, y se llaman veneras" - y también conchas de peregrino, o de Santiago ${ }^{19}$. Finalmente, a menudo lo que falla en D. Alonso es la interpretación (ejemplos: la pesadumbre de I: 170 no es la del monte, sino la de la piedra de Sísifo; el furor del viento I: 349 no se ensaña contra la corriente del arroyo, sino contra los árboles; la náutica industria que "investigó" la piedra imán I: 379 no se refiere al descubrimiento del imán, sino a su aplicación a las artes navales; el mudo de I: 687 no va con silencio, cosa redundante, sino con triunfo; la dulce vena de II: 14 no significa que el arroyo baje "mansamente", sino que es de agua dulce; el sueño de II: 676 no es el sueño "de los mortales" en general, sino el del peregrino; y en I: 839 no se desea que las muchachas borden la historia de Aracne, sino que rehúyan su arrogancia). En dos casos por lo menos (II: 497 y II: 749), la adición de una simple coma pone el texto de Jammes indudablemente por encima del de Alonso.

Comparar la edición de Jammes con la de Alonso es casi como comparar las fotos que ahora tenemos de Júpiter y Saturno con las existentes hace pocos años. ¡La cantidad de "pequeños detalles" que se han descubierto en estos planetas gracias a las naves espaciales y a las novísimas técnicas fotográficas de "alta resolución”! ¡La can-

18 Podría discutirse esta interpretación (por puro afán de discutir, puesto que estoy de acuerdo con ella). Dice Jammes que "a principios de mayo" no hay membrillos, lo cual es cierto (estarán apenas en flor), pero dice también: "es poco agradable, por no decir imposible, comer membrillos crudos", lo cual me parece ligeramente calumnioso: me consta que un buen membrillo maduro ("datilado", no verde) es bastante sabroso, sobre todo si se acompaña, como las manzanas ácidas, con algo de sal o de azúcar. Además, los membrillos guardados entre paja concentran lo que tienen de dulzor, y quizá los membrillos comidos "a principios de mayo" eran los de octubre o noviembre del año anterior. También se puede argüir que Polifemo no se pondría a hacer pasta con los membrillos que cargaba en el zurrón. Por lo demás, en el texto de doña Oliva Sabuco citado en nota a I: 872 se menciona la "carne" del membrillo (pasta, conserva, el ate mexicano) y, aparte, también el membrillo.

${ }^{19}$ En la versión primitiva de I: 309 ss. se refería Góngora a la rueda del pavo y decía: "destinada la veo / a guloso himeneo". D. Alonso sugería leer "destinado te veo", pues la rueda del pavo es todo menos "comestible"; pero Jammes le contesta que no hay error: "solían, y suelen todavía, en algunos banquetes de prestigio, servir el pavo con su rueda reconstituida". 
tidad de "pequeños detalles" que Jammes deja aclarados! ¡Qué afán suyo por llegar a la mayor nitidez posible, sin dejar basuritas bajo la alfombra! Por ejemplo, lo que hay que saber acerca del salmón II: 99, o del doral II: 834, o de las colmenas I: 925, o de la costumbre de comer cisnes II: 25420. El impresionismo, el "más o menos", ha cedido una y otra vez su lugar a la "alta resolución".

Muchas de las precisiones que aporta Jammes son de índole técnica. "Uno de los pasajes más complicados... y uno de los más curiosos", el de II: 179-184, queda ahora admirablemente aclarado: Jammes explica punto por punto las metafóricas transacciones "bancarias" que aquí se llevan a cabo. (Cf. también I: 546 sobre $l i$ brar, y II: 828 sobre debery término prescripto.) He aquí algunos otros ejemplos: el "mecanismo" de la comparación del arroyo con un instrumento de cuerdas (I: 347); la reconstrucción de "lo que serían los bailes de aldea" (I: 669); la reflexión sobre los manjares campesinos (I: 880); la absoluta verosimilitud del salto que dio el montañés en los juegos nupciales (I: 998, con mención del actual record olímpico); la existencia de jeux d'eau en Aranjuez (II: 224); la identificación del "príncipe" halconero (II: 811) con el Conde de Niebla (y no con el Duque de Béjar); el hallazgo de que las aguas marinas de I: 417 no son 'aguas del mar', sino plural de aguamarina, piedra preciosa "de luminosidad transparente, entre azul y verde", elemento importante de la "sinfonía en azul" que es este breve pasaje (Jammes convence de tal manera, que hasta valdría la pena imprimir aguasmarinas) ${ }^{21}$. Mencionaré por último el aná-

${ }^{20}$ Yo, francamente, no me había preguntado por qué el modesto pescador criaba cisnes, aves tan aristocráticas y poéticas. Ahora me entero de que eso era entonces como criar gallinas o gansos. Aún más: "Muy recientemente ha vuelto a ponerse de moda el comer cisne". (La imagen del "armonioso número de blancos cisnes" entre los verdes carrizales de la isla será desarrollada por Góngora en 1620 en la delicadísima letrilla "Ánsares de Menga..."; pero la comestibilidad de los ánsares, aunque igualen a los de Menga en blancura, siempre ha sido conocida.)

${ }^{21}$ A propósito de aguasmarinas, he aquí una observación muy marginal. El soneto "En tenebrosa noche, en mar airado...", escrito para una justa con motivo de la beatificación de San Ignacio (y no premiado por el "injusto" P. Pineda), termina con un pie forzado: "ardiendo en aguas muertas llamas vivas". Es alusión "a la rigurosa acción con que San Ignacio redujo a un pecador", metiéndose hasta el cuello en un estanque helado para "enfriar" los ardores lujuriosos de cierto adúltero. Las aguas muertas son, pues, las del estanque helado. Pero también (según Luzán, Poética, lib. II, cap. 15) hay un juego de palabras, pues eso ocurrió "en un lugar que tiene por nombre Aguas muertas". Y como San Ignacio anduvo por tierras de Francia, pienso que ese lugar será Aiguesmortes (Aguasmuertas), no lejos de Montpellier. 
lisis del largo discurso del "político serrano" (I: 360 ss.), con las precisiones sobre los viajes de descubrimiento y conquista (v.gr. notas a 430 y 435) y las observaciones sobre la "curiosa personalidad" de ese serrano (notas a 530, 594, 653).

Pero no siempre es posible la precisión. Aquí y allá quedan - y quedarán quizá para siempre- dudas flotando. Jammes entiende (y yo también) que el garbín de II: 265 lo hizo el viejo en su mocedad, pero dice que "no se debe rechazar" la posibilidad de que lo haya hecho uno de los hijos; así también, el "que a mucha fresca rosa..." de I: 569 "se puede interpretar de dos maneras"; la interpretación que él prefiere "parece corresponder mejor al gusto de Góngora" (en lo cual estoy de acuerdo), pero quienes prefieran la otra están en su derecho ${ }^{22}$. Y, en verdad, cuando se analizan de manera cuasi-microscópica dos posibles interpretaciones, llega un momento en que nos topamos con la in-diferencia: ¿qué más da si la orza de I: 327 contiene trozos de panal o simplemente miel (como cree Jammes)? ¿Y qué importa si el vuelo de II: 482 es de la deidad o del dardo? (Cf. también I: 187, I: 769, I: 1030, II: 129, II: 823 y II: 916.) Cuando Jammes confiesa: "no sé a qué tradición se refiere" (sierpes del Ponto I: 600), o: "no hallo otro ejemplo" (de vial como sustantivo, I: 704), o: "no me atreveré a decir que el problema [de I: 1012] esté definitivamente resuelto", podemos tener la seguridad de que nos hallamos en la frontera de lo averiguable.

Un terreno muy bien cubierto por los comentaristas antiguos es el de las "imitaciones" de los clásicos. Aun así, los comentaristas modernos han ampliado este terreno. Jammes, por supuesto, recoge todos los señalamientos de "fuentes" clásicas, pero no se queda allí, sino que aprovecha los datos como materia prima para reflexionar agudamente sobre la manera como Góngora supo utilizarlas, revivificándolas. Son admirables los análisis de varias de es-

${ }^{22}$ En las pp. 111-113 de la Introducción agrupa Jammes varios casos en que la frase, a causa del hipérbaton, admite dos construcciones posibles. Uno de ellos es "...y la que desviada / luz poca pareció, tanta es vecina...", donde el $l a$ fue interpretado por Salcedo como artículo ("la luz que le pareció de lejos tan pequeña...”), y por Pellicer como pronombre ("la que desde lejos había parecido luz poca...”). Tras observar que D. Alonso coincide con Salcedo, y A. Carreira con Pellicer, añade Jammes: "Miro ahora mi propia paráfrasis, y veo que, sin advertir que había un problema, he seguido a Salcedo y D. Alonso... Lo siento, porque en el fondo me gusta más la versión de Pellicer y de Carreira; pero no voy a corregir la mía que, gramaticalmente, es tan legítima como la otra. El lector podrá escoger la que mejor le convenga, teniendo en cuenta únicamente, él también, sus propias razones subjetivas" (p. 113). 
tas utilizaciones: Virgilio (I: 152), Claudiano (I: 275, I: 611, I: 793), Plinio (II: 297). A propósito de una conocida "imitación" de Juan de Mena ("que mármol de Paro parece en albura" > "mármol, al fin, tan por lo pario puro" II: 698) hace Jammes una reflexión atinadísima: "No conviene... hablar de «imitación", concepto que llega a ser una verdadera manía en los comentaristas antiguos". Para ellos, en efecto — como para el Brocense y Herrera-, el "imitar" a Horacio, Virgilio, etc., era por sí solo una señal de maestría, y allí se quedaban ${ }^{23}$. Jammes propone dejar a un lado la idea de imitación, tan angosta, y hablar mejor de alusión, "con lo que implica siempre, en Góngora, de humor discreto y de complicidad con el lector, en la mente del cual quiso despertar aquí [en II: 698] el recuerdo de su paisano Juan de Mena, como hizo en otros casos con Virgilio, Claudiano y, a cada paso, con Garcilaso". Sin duda, alusión es mejor. Y yo añadiría: homenaje.

Este "homenaje" es especialmente visible en el caso de Garcilaso. Porque, tantos años después de su muerte, Garcilaso seguía siendo el poeta por antonomasia, el siempre leído, el nunca olvidado: era "nuestro Petrarca". Muchos de los lectores de las Soledades desconocerían a Claudiano (de manera que sólo unos cuantos, the happy few, gozarían las alusiones a él), pero ciertamente todos conocían a Garcilaso. Al leer "aquella sierra engendradora / más de fierezas que de cortesía" (I: 136) se acordaban de "Si en la arenosa Libia, engendradora / de toda cosa ponzoñosa y fiera" (Elegía II); al leer "mantenía / la vista de hermosura" (I: 268) se acordaban de "sus ojos mantenía de pintura" (Égl. II), y al leer "morro difícil, cuyas rocas / tarde o nunca pisaron cabras pocas" (II: 398) se acordaban del "monte de aspereza fiera, / pisado tarde o nunca de pie humano" (Égl. III). Claro que la idea de homenaje va siempre

${ }^{23}$ Fernando de Herrera, que tan entusiastamente celebra en sus Anotaciones los lugares en que Garcilaso "imita" a los antiguos, dice que la ciencia de la imitación anda de capa caída: "Si me preguntan por qué entre tantos millares de poetas como nuestra España tiene, tan pocos se pueden contar dignos de este nombre, digo [que es porque les falta ciencia] para saber imitar". Y Lomas Cantoral se había quejado poco antes de que, "siendo los españoles tales" que aventajan a las demás naciones en cuanto emprenden, "y siendo también la lengua española tan capaz de poesía”, estuviera España tan por debajo de Italia, y aun de Francia. ¿Y por qué? Porque italianos y franceses "tienen instituidas públicas academias donde no se profesa otra cosa [que la imitación], y con ella han enriquecido su lengua y adornádola con nuevos números y ritmos". Garcilaso, "movido de los italianos..., en la parte que imita a los latinos fue excelente y divino"; pero, hasta la fecha (1578), no ha tenido sucesores. Cf. NRFH, 36 (1988), pp. 969-970. 
trabada con la de emulación o competencia. Como si Góngora nos dijera: "Garcilaso, con sus medios, hizo esto; yo, con los míos, hago esto otro". Afán de emulación que venía de lejos, como lo muestran los dos sonetos — "Mientras por competir con tu cabello...", de 1582; "Ilustre y hermosísima María...", de 1583 - en que dejó como nuevo el famoso de Garcilaso. El canto del peregrino ("¡OH bienaventurado / albergue a cualquier hora!...”, I: 94 ss.) es una reelaboración del Beatus ille de Horacio, pero, más directamente, del canto de Salicio (“¡Cuán bienaventurado...!”) en la Égloga II. El canto amebeo de II: 542 ss. se remonta ciertamente a Virgilio (o a Teócrito), pero sin duda Góngora piensa ante todo en el que hay al final de la Égloga III, tal como en la dedicatoria de las Soledades y en la escena de cacería de II: 831 ss. está sobrepujando la dedicatoria de la Égloga I y la escena de cacería de la Égloga II, 185 ss. ${ }^{24}$ Además, se puede hablar de ciertos "garcilasismos" de tal manera adoptados por Góngora, que ahora los sentimos más bien como "gongorismos". Si Góngora no hubiera encontrado una gracia especial en el perdonar a de "sin perdonar al blanco pie corría" (Égl. III, 154), no lo habría imitado una y otra vez (cf. la nota de Jammes a II: 495, y añádanse otros dos casos: II: 676 y II: 707). El gusto por las diéresis latinizantes o italianizantes (glorïoso, inquïeto, etc.), tan denostado por Jáuregui como manía de Góngora, no es sino aceptación de las diéresis de Garcilaso. Y aquí entra de manera muy especial el acusativo griego. Cuando leemos "el fiero cuello atados" (Canción V) y sobre todo "las venas dulcemente desatado" (Elegía II, 144), nos parece que Garcilaso está gongorizando. ¡Cómo se complace Góngora en la elegancia, la precisión, la economía poética del acusativo griego! Verdaderamente pone en él su "marca de fábrica".

Yo creo que otro aspecto del "homenaje" de Góngora a Garcilaso es la incorporación de la mitología grecolatina en el mundo moderno. En la Égloga III una ninfa clásica borda en su tela delicada el Toledo de Carlos V, con su alcázar y su catedral, y en la Égloga II otra ninfa, Camila, toma terriblemente en serio el culto de Diana, pero estamos junto a la ribera del Tajo. Estos entreve-

${ }^{24} \mathrm{El}$ hecho de que las dos dedicatorias sigan brillando en nuestros "democráticos" tiempos, aborrecedores de la adulación a los poderosos, es, pienso yo, una especie de garantía de su belleza perdurable. En cambio, creo que las escenas de cacería repugnan a nuestra mentalidad "ecológica”. ¡Pobres pájaros!, pensamos (zorzales y estorninos en Garcilaso, dorales y cuervas en Góngora). Claro que no pensaba así Garcilaso ("era vellos una cosa / extraña y agradable, dando gritos...”), ni tampoco Góngora (“estos pendientes agradables casos...”). 
ramientos de la mitología en la trama narrativa los hay también en las Soledades: 1) los racimos que coronan la frente de Baco han sido mordisqueados por un macho cabrío (I: 155); 2) en cierto momento se congregan a orillas de un arroyo tantas serranas, que se diría que superan en número a las Hamadríades, brotadas allí mismo de sus moradas vegetales (I: 259); 3) a otro día, Himeneo despierta a Febo (I: 705), el cual, acto seguido, monta en su luminoso carro (I: 709); 4) se canta luego un Epitalamio empapado en paganismo (I: 767 ss.); 5) al final de ese día, Himeneo vuelve a entrar en escena para apresurar la aparición del lucero vespertino (I: 1067); 6) hay después un viejo pescador que teme a los Tritones, pues los tiene bien conocidos (II: 461); 7) hay un dios -o una diosa- que dirige, como en la Ilíada, el vuelo de un dardo (II: 485); 8) hay doncellas que se llaman Éfire, Filódoce, Cloris y Leucipe (no Teresilla o Menga), y mancebos que se llaman Lícidas y Micón (no Gil o Pascual); 9) mientras Lícidas y Micón cantan, se ve venir a Cupido, surcando las aguas en una navecilla y usando sus flechas como remos (II: 519 ss.); 10) el mismo Cupido, haciendo las veces de Mercurio, se encarga luego de comunicar una buena noticia (II: 648); 11) al día siguiente, las Horas se ocupan en enjaezar los caballos de Febo (II: 677 ss.), y 12) hay un glorioso intercambio de relinchos entre ellos y los caballos terrestres (II: 730 ss.)

Todos estos pasajes están, según yo, integrados en la trama narrativa. Los he reunido para contradecir (un poco) a Jammes, el cual, reconociendo naturalmente el denso trasfondo ovidiano de tantas imágenes y alusiones gongorinas - por ejemplo Europa, Ganimedes y Arión en el comienzo mismo de las Soledades-, critica a quienes han llegado a creer "que la poesía de las Soledades es un eco permanente de la mitología grecolatina", negándole casi a Góngora la capacidad de "ver directamente el mundo que lo rodea” (p. 138). La crítica no podía ser más justa, pero la reacción me parece excesiva. Como si hubiera previsto la lista de pasajes mitológicos que yo acabo de dar, dice Jammes en nota a I: 261 que "el único caso de intrusión real de creencias mitológicas en la trama narrativa" es el Epitalamio, y en nota a I: 779 insiste: "Es de notar que esta escena de una ceremonia religiosa ${ }^{25}$ es la única en que

${ }^{25}$ Me detengo en esto. Los novios unidos por el sacramento del matrimonio pertenecen al mundo real, y hay aquí naturalmente una iglesia pueblerina, y un cura que dice la misa y pronuncia el sermoncito. Pero sobre esta realidad de orden religioso pasa Góngora como sobre ascuas cuando dice que el "dulce alterno canto" se dejó oír al salir los novios "del vecino templo santo". En un caso 
el poeta, abandonando toda conexión con el mundo de su tiempo, que constituye el argumento del poema, nos transporta a la antigüedad pagana”. (Y cf. pp. 138-139, nota 126.) Después, en nota a II: 464, añade un caso más: los Tritones. Así, pues, Jammes no "acepta" sino dos de los pasajes mitológicos de mi lista (los núms. 4 y 6). En nota a I: 261 casi admite que lo que estamos presenciando es "una aparición real de ninfas paganas en medio de estas serranas españolas del siglo xviı" (el núm. 2 de mi lista), pero de los demás pasajes no dice nada.

He aquí, para terminar, algunas observaciones de detalle. Las hago tímidamente, y consciente de que muchas de ellas son minucias. Pero creo que, al ponerlas por escrito, estoy siguiendo las huellas de Jammes.

D: 3.] en soledad confusa. "Hay — dice Jammes- dos construcciones posibles, según se considere este complemento relacionado únicamente con el participio perdidos, o con los dos participios perdidos e inspirados". La primera solución es la de D. Alonso: "pasos y versos, perdidos unos en confusa soledad, inspirados otros", y también, de manera aún más explícita, la de Jammes: "perdidos en soledad confusa los unos (los pasos), inspirados los otros (los versos)". La segunda solución es la de Pellicer: "perdidos en la soledad los pasos, y en la soledad dictados los versos". Pero Pellicer pasa aquí en silencio la palabra confusa, que es la que nos interesa, y creo que esta palabra, que no es propiamente adjetivo, sino participio latinizante del verbo confundir (cf. la nota de Jammes sobre "confuso Baco" I: 868), no ha merecido la atención que debiera.

En primer lugar, Góngora parece haber hallado muy sugerente el verso de Garcilaso (Canción V) "y al son confusamente los

así, Lope de Vega nos habría obsequiado una bonita escena "costumbrista"; pero no Góngora (sobre todo, no en las Soledades). Ocurre aquí lo que en el soneto "Deste más que la nieve blanco toro...", donde, ante la obvia imposibilidad de decir poéticamente 'A Dios y a la Virgen María les pido que restituyan la salud a mi querido prelado', lo que hace el clérigo Góngora es convertirse en un pastor clásico que en el altar de Apolo sacrifica un toro. (El soneto es de 1586, y en ese mismo año murió el prelado, de manera que el sacrificio del toro no sirvió de nada.) Parecido a éste es el soneto "Los rayos que a tu padre son cabello...", donde el cortesano Góngora promete inmolarle un toro a Esculapio, hijo de Apolo, si el rey sana de su enfermedad. (El soneto es de 1621; según el ms. Chacón, el enfermo era Felipe III, que murió ese año, pero evidentemente se trata de una enfermedad del joven Felipe IV, el "garzón bello" del v. 5.) 
trujese" (las fieras y los árboles siguiendo indiscriminadamente, revueltos unos con otros, la irresistible música de Orfeo), como lo muestra el hecho de que no pocas veces siguió ese ejemplo: "confusas entre los lilios / las rosas se dejan ver" (Millé 70); la tez juvenil de Tisbe "vaso era de claveles / y de jazmines confusos" (Millé 74, w. 55-56). Véase también Millé 190, "lo que se confunde" en un requesón: la leche y la miel están allí confusas ${ }^{26}$.

Ahora bien, lo primerísimo que hace Góngora, en esta Dedicatoria tan exquisitamente meditada, es asentar una ecuación: tema $=$ forma $($ mundo $=$ poesía, o como se quiera decir $)$. El peregrino vaga en íntima soledad, con lo que lleva puesto, sin plan de viaje, pero con los ojos muy abiertos. Y, por inspiración de una dulce Musa, Góngora ha identificado con la del joven héroe su propia soledad íntima, su altísimo ideal poético, su incansable búsqueda de la forma ${ }^{27}$. A diferencia de la forma rigurosa y cuasi-geométrica del Polifemo, la de las Soledades es suelta, "sin plan de viaje", verdaderamente silvestre. No hay que olvidar que la silva era en 1613 una novedad. De septiembre de ese año es la famosa "Carta de un amigo" (comentada por Jammes en las pp. 612-614), que comienza así: "Un cuaderno de versos desiguales y consonancias erráticas ha aparecido en esta Corte con nombre de Soledades". En efecto, consonancias erráticas que "consuenan" con los pasos errantes del peregrino (y así, en D: 31 los "errantes pasos" son los versos de la silva) ${ }^{28}$.

Así, pues, yo siento que el "complemento" en soledad confusa abarca por igual los pasos perdidos del peregrino y el libre fluir de los versos del poema. Así como en "vaso era de claveles / y de jaz-

${ }^{26}$ Cf. la nota de Jammes sobre "sus confusos senos" (II: 287): "senos, porque las madrigueras [de los conejos] están en la profundidad del suelo; confusos, porque están como enmarañadas unas con otras". En la nota a I: 534 (pasaje en que no aparece la palabra confuso) cita Jammes el comentario de Salcedo: "La selva, cuyos árboles, si bien no estaban dispuestos en forma de calle, o carrera, por estar confusos, era tan apacible su confusión que...”.

${ }^{27}$ Góngora subraya esta identificación en el soneto "Restituye a tu mudo horror divino...", del cual me ocupo en el apéndice.

${ }^{28}$ En 1613 se habían escrito ya algunos poemas, o pasajes de poemas, en metro de silva (Góngora mismo lo había ensayado en varios pasajes de Las firmezas de Isabela, de 1610, y en el poemita "Por este culto bien nacido Prado...", de 1612), pero, como dijo Faria y Sousa, "las primeras [silvas] que uvo en Castellano (a lo menos cultas, i grandes en cantidad de versos) fueron las Soledades de Góngora". Véase Eugenio Asensio, "Un Quevedo incógnito: las silvas", Edad de Oro, 2 (1983), 13-48, y A. Alatorre, "Quevedo: de la silva al ovillejo", Homenaje a Eugenio Asensio, Gredos, Madrid, 1988, pp. 19-31. 
mines confusos" la palabra confusos no se aplica sólo a los jazmines, así también las palabras en confusa soledad no se aplican sólo a los pasos. No de otra manera, en I: 868 ss. es tal la mezcla, la confusión de los vinos, que los rubíes del tinto y los topacios del blanco intercambian sus epítetos (que es como cuando el Amor duda cuál sea el color de Galatea: "o púrpura nevada o nieve roja"). Completando la explicación de Pellicer, yo diría: "tan en soledad perdidos los pasos y tan en soledad inspirados los versos, que se borran, se confunden los límites entre lo uno y lo otro"29.

I: 11.] da al mar, que condolido... Dice Jammes: "Anacoluto.... el sujeto de los versos que siguen no es el mar, ...sino el misero gemido". Lo que yo creo es que nos hallamos ante un latinismo sintáctico, un ablativo absoluto. El pronombre que no está en "nominativo", por supuesto, sino en "ablativo" (= "dat mari, quo miserto...", etc.). $\mathrm{Y}$, en efecto, la prosificación de Jammes suena a traducción de un ablativo absoluto: "habiéndole compadecido el Océano...", etc. Lo mismo sucede en II: 467 ss.: 'un corcho, despedido el cual...' (= quo emisso, quo iacto), etc. También, creo yo, en II: 726-727: 'habiendo quedado la yegua preñada del céfiro...', etc. Góngora es aficionado a los ablativos absolutos. Por lo general son breves: "calmas vencidas y naufragios" I: 456, "tal vez creciendo..." I: 607-608, "su nocivo diente..." II: 312-313, "rudamente dadas..." II: 361-363; Jammes llama la atención sobre uno bastante largo, nota a II: 427.

I: 43.] que hacian desigual, confusamente / montes de agua y piélagos de montes. Dice Jammes: "Breve e impresionante visión de un paisaje de tempestad, al anochecer, sintetizada en una hipálage". Yo creo que esto no está bien. La tempestad que causó el naufragio ha quedado muy atrás, por así decir. El Sol de mayo ha sido lo bastante fuerte para chupar la menor onda al menor hilo del traje del náufrago, y ahora nos hallamos en un crepúsculo muy normal: desvanecido el oro en los horizontes de Occidente, mar y tierra quedan de tal manera hundidos en la penumbra, que el peregrino no sabe si está viendo montes de agua o piélagos de montes: confusión total: confusamente (imposible distinguir qué es qué) ${ }^{30}$. El otro ad-

${ }^{29}$ A propósito del himno “¡Oh bienaventurado / albergue...!" (I: 94 ss.) cita Jammes a A. Carreira, según el cual "se puede tomar por pensamiento del poeta o del peregrino". Justamente! Muy buen ejemplo de "confusión”.

30 Tampoco la gongorina Sor Juana sabe qué es qué cuando dice (romance "Agora que conmigo...", vv. 21-24): “...salgan confusamente / suspiros que me abrasen, / lágrimas que me aneguen”. 
verbio, desigual[mente], está puesto muy adrede porque hay una "diferencia específica": no puede compararse la horizontalidad del mar (ni siquiera cuando hay tormenta) con la verticalidad de los montes.

I: 61.] A propósito del vocabulario marítimo de este pasaje, y aduciendo el "menos cansado que confuso" del v. 51, observa Jammes: "Todavía aturdido por la tempestad de la que acaba de escapar, el náufrago percibe en este paisaje nocturno como una visión marítima". Yo, francamente, no veo la necesidad de acudir al trauma del naufragio para explicar esta cuidadosa expansión del tópico 'llegar a puerto tras un viaje azaroso'. El peregrino está ciertamente cansado por la escabrosa caminata cuesta arriba, y, más aún que cansado, confuso por esa caminata tan a ciegas (porque no hay luna), hasta que por fin entrevé, a lo lejos, la lucecita de la cabaña. Una señal de que Jammes está excesivamente obsesionado con la idea del naufragio es su comentario a I: 349: la interpretación de "en cuanto a su furor perdonó el viento" me parece irreprochable: "mientras soplaba el viento [en los árboles], el arroyo no podía oír la música del agua en las piedras"; pero no veo razón para decir que esto "recuerda la tempestad del día precedente"31.

I: 73.] piedra, indigna tiara. Todo el mundo está de acuerdo en que esta piedra es el carbunclo. Pero, en contraste con la mucha información sobre la extraña naturaleza del carbunclo - comenzando con las tres redacciones que hizo Góngora de los vv. 73-76 y lo que sobre este pasaje dijeron los comentaristas antiguos-, es notable lo a oscuras que estamos en cuanto al "funcionamiento real" de esa piedra deslumbrante. El mecanismo de la comparación es muy claro: así como los villanos caminan con la mayor facilidad por la fragosa montaña "guiados por el carbunclo", así el peregrino..., etc. (D. Alonso); "de la misma manera que el villano sigue atentamente aquella piedra..., de esta manera el mancebo...", etc. (Jammes). Pero ¿cómo "se les aparecía" el carbunclo a los caminantes? Z. Milner tuvo cierta razón al sugerir que por carbunclo se entendiera 'la constelación del Carro' — pues nada más natural para un caminante que guiarse por las estrellas

${ }^{31}$ No deja de ser curioso que D. Alonso, en nota sobre las "trágicas ruinas" de II: 384, sienta análogamente que el peregrino alude no sólo "a algún navío que hubiera naufragado en aquellas costas", sino también "a su propio naufragio". 
(en noches despejadas, se entiende)—, pero obviamente aquí no se trata de eso, ya que la piedra en cuestión es clara "aun a pesar de las estrellas". Aquí, creo yo, la explicación de Díaz de Rivas es más "completa" que la de Alonso y Jammes: la "tradición apócrifa" se refiere no sólo a la piedra que cierto animal tiene en la cabeza, sino también al provecho práctico que los villanos sacan de su extraordinaria luminosidad.

I: 112.] Entre los horrores de la vida en la Corte, a continuación de "la que se alimenta de áspides", o sea la Envidia, menciona el peregrino a "la que en vulto comenzando humano / acaba en mortal fiera, / Esfinge bachillera / que hace hoy a Narciso / Ecos solicitar, desdeñar fuentes". ¿A qué se refiere Góngora? Para D. Alonso, este pasaje es buen ejemplo de las "dificultades invencibles" que a veces hay en las Soledades: la imagen es "tan vaga", que se presta a las varias interpretaciones dadas por los comentaristas. No sin reservas, él adopta la de Salcedo: esa Esfinge bachillera es la Disimulación. Comentando el soneto "No entre flores, no...", el mismo Salcedo dice que en el verso "Sirena dulce, si no Esfinge bella" la Esfinge "simboliza el Engaño", y remite a nuestra "Esfinge bachillera". (Cf., por otra parte, el soneto "Valladolid, de lágrimas sois valle...": "Pisado he vuestros muros calle a calle, / donde el Engaño con la Corte mora".) La interpretación de Jammes es muy distinta. Él observa que las caracterizaciones de la Ambición y de la Envidia, en versos anteriores, recuerdan sendos emblemas de Alciato - aunque (pienso yo) para la de la Envidia pudo Góngora recordar directamente a su muy leído Ovidio (Met., II, 768 ss.: "videt intus edentem / vipereas carnes... Invidiam"). Ahora bien, a propósito de la Esfinge menciona Díaz de Rivas un tercer emblema de Alciato, "Submovendam Ignorantiam", en el cual se apoya Jammes para ver en la Esfinge el símbolo de la Ignorancia; concretamente, "la ignorancia del presumido, que no quiere conocerse a sí mismo".

Su razonamiento me parece más laborioso que convincente. Esa ignorancia de índole filosófico-moral (cuyo remedio es el nosce teipsum) se da en todo el género humano; no está "en serie" con los otros males, no es algo privativo de la Corte. La Disimulación, en cambio, es característica suya en grado eminente. Allí nada es consistente. Los cortesanos son Narcisos que abandonan la límpida Fuente y corren tras el Eco, que es aire, que es nada. Engaños, maquinaciones, intrigas, promesas falsas, palabrería tramposa, sonrisas "humanas" que encubren intenciones "mortales": eso es 
la Corte ${ }^{32}$. Viéndolo bien, si Góngora no hubiera incluido a la Disimulación, su catálogo habría quedado manco.

I: 233.] Bajaba (entre sí) el joven admirando... Yo creo que los paréntesis estorban al sentido: el joven bajaba admirando entre sí, silenciosamente, al extraño cabrero.

I: 411.] Los viajes de descubrimiento, en Oriente lo mismo que en Occidente, tuvieron como piloto único — sin admitir segundo- a la Codicia. Como paladinamente lo expresa Díaz de Rivas al anotar este pasaje: "La cudicia sola fue la causa..., sin admitir otro fin segundo [ni siquiera segundo] de celo de religión o de curiosidad". Tengo para mí que Díaz de Rivas fue lector de Pedro Mártir de Anghiera, el cual, en sus décadas De Orbe Novo, a la vez que subraya la insaciable codicia de brutos como Pedrarias Dávila, se burla con mucha ironía de su celo de religión (los multitudinarios bautizos al vapor de los indios despojados por él), y que todo el tiempo está mostrando su enorme curiosidad personal por las novedades de los mundos nuevos (el occidental y también el oriental), tan en contraste con la actitud de los conquistadores españoles ${ }^{33}$. Quizá Góngora mismo leyó a Pedro Mártir. Y cabe imaginar lo que serían sus conversaciones con el Inca Garcilaso, buen conocedor de lo que había sido la conquista, y además lector de Jean Bodin. (Yo siempre he pensado que la espléndida imagen de la "augusta Coya peruana”, en II: 66, es un homenaje de Góngora a quien era

${ }^{32}$ Jammes observa que Díaz de Rivas, aunque “descubridor” del emblema de Alciato, no siente que la Esfinge bachillera de Góngora aluda a la Ignorancia, sino a "las damas de palacio" y sus embelecos. (En mi interpretación, estos embelecos no serían sino un ejemplo de las múltiples insidias de la Corte.)

-En el texto de Díaz de Rivas que cita Jammes en la p. 592 se lee que las damas de palacio "son tan discretas y junctamente tan lisonjeras y atractivas, que a los hombres, y a los más narcisos..., los hacen que dejen las fuentes". Jammes cree que falta algo, e imprime: "tan lisonjeras y atractivas, que [mueven?] a los hombres..."; pero la frase se entiende perfectamente tal como está. - Por otra parte, explica Jammes que el Narciso cortesano "solicita a la ninfa Eco, es decir busca quien lo halague, asintiendo a sus palabras como un eco"; pero esto coincidiría con la Adulación, que viene después.

33 Un español que sí tuvo esa curiosidad (con la ventaja de haber vivido durante largo tiempo en el Nuevo Mundo) fue Gonzalo Fernández de Oviedo; pero la publicación de su gran Historia quedó interrumpida, por real orden, en el primer tomo. El De Orbe Novo fue poco leído y nunca se tradujo. Cf. A. AlaTORRE, "Pedro Mártir y el Nuevo Orbe", en Reflexiones lingüisticas y literarias, t. 2: Literatura, eds. R. Olea Franco y J. Valender, El Colegio de México, México, 1992, pp. $67-85$. 
amigo y vecino suyo.) Con razón dice Jammes que este pasaje es "poco ortodoxo". Los ortodoxos como Salcedo y Pellicer — cuyos aspavientos cita- abrazaban la "verdad oficial", la de Solórzano Pereira, la de López de Gómara, la de Antonio de Herrera, empeñados en combatir a los herejes y extranjeros "calumniadores" de España. ¿Qué enorme distancia —intelectual y humana- entre Góngora y esos ortodoxos! Góngora estaba convencido de que el motor de todas las empresas fue la codicia ${ }^{34}$. Hay en la réplica de Pellicer un dato de mucho interés: dice que esos libros antiespañoles —el más famoso el de Girolamo Benzoni (1565), muy reeditado en Europa- están en el Index librorum prohibitorum et expurgatorum de 1612. La fecha 1612, observa Jammes, "permite vislumbrar el ambiente polémico en que caían" estos versos, - escritos además tan adrede. La visión crítica y la ausencia de chauvinisme es uno de los rasgos que emparientan a Góngora con Cervantes.

I: 423.] los que armó de plumas ciento / Lestrígones el istmo, aladas fieras. Las plumas son evidentemente, como dice Jammes, las del "atuendo" de los indios —o de su "armadura", diría yo mejor en este caso-, y no alusión a la ligereza de sus flechas. Se puede añadir que las flechas han quedado ya mencionadas en el v. 419: "áspides volantes", flechas de punta envenenada. (Después, en II: 780, admiraremos "al vestido de plumas Mexicano".) Yo pongo acento en Lestrígones, pues dudo que Góngora hiciera llana una palabra tan eminentemente culta como Laestrigönes (debe ser tan esdrújula como, por ejemplo, Zodíaco I: 466). Vale la pena observar cómo, en vez de comparar a los indios americanos con pueblos específicamente famosos en la tradición histórica europea por sus hazañas "flecheras", Góngora decide compararlos con los homéricos Lestrígones, tan perdidos en la lejanía del mito. Cf. supra, nota 3, las palabras de Jammes sobre lo "primitivo" y la "palingenesia". Es como si el poeta hubiera querido engazar la novedad del Nuevo Mundo con la más arcaica Antigüedad. Él nunca deja de lado la tradición clásica, pero la amplía, la actualiza, la enriquece.

${ }^{34}$ Cf. la nota de Jammes a II: 899: "que a las estrellas hoy del firmamento...": "Pasó inadvertido de los comentaristas, al parecer, este casi imperceptible hoy con el que Góngora insinúa, no por cierto que las cuervas hayan «mudado las mientes» recientemente, sino que la codicia ha llegado a ser la principal plaga de la España de su tiempo, de modo que este verso — sonoro, luminoso- adquiere inesperadamente un alcance satírico y festivo". Sí, inesperadamente; y eso es lo más significativo. 
Es "entre las conchas hoy del Sur" donde Febo esconde "sus muchos años" (II: 774), no ya en el "famoso estrecho" de Gibraltar, extremo occidental del mundo antiguo. El Mediterráneo es hoy un modesto estanque (I: 400), pero Febo, pese a sus muchos años, sigue resplandeciendo ${ }^{35}$.

I: 453.] Los astronómicos presagios de este verso, dice Jammes, "no sé exactamente a qué aluden". Yo propondría ligarlos simplemente con la náutica doctrina del verso siguiente: hasta finales del siglo xv, las cartas de navegación ("náutica doctrina") se apoyaban en las especulaciones de los cosmógrafos "clásicos" sobre la inhabitabilidad de la Zona Tórrida ("astronómicos presagios"). Pero los descubridores no se arredraron por lo uno ni por lo otro.

I: 496.] clavo no, espuela sí del apetito. Jammes reproduce y explica el comentario de Salcedo sobre la relación antitética de clavo y espuela. Cabría aquí una mención del soneto "¡Oh niebla del estado más sereno...!", traducción-paráfrasis del "O gelosia...!" de Sannazaro: éste dice sólo "d'amanti orribil freno", y Góngora amplía y redondea la imagen: "de la amorosa espuela duro freno".

I: 609.] caracteres tal vez formando alados. Así imprime Jammes. Pero si en la primera redacción se leía "cuando no ya carácteres alados", ¿no es claro que la palabra era esdrújula para Góngora?

I: 614.] las que Sidón, telar turquesco... Así imprime Jammes; y explica: "Sidón, célebre en la Antigüedad por sus tejidos teñidos de púrpura, y ahora por sus alfombras turquescas", añadiendo que "para los contemporáneos de Góngora había continuidad entre la producción antigua y la moderna". Tal es, sin duda, el sentido; pero este sentido sobresale mejor si el telar lleva simultáneamente dos adjetivos caracterizadores: sidón y turquesco. (Para el sintagma "sidón telar turquesco", adj.-sust.-adj., cf. "pendientes sumas graves" I: 291, “doméstico nuncio canoro" I: 294, etc.) El texto que imprime

${ }^{35}$ El pasaje termina con los versos "sierpe de cristal..., / ...cola escamada / de antárticas estrellas", que Jammes califica de "soberbios". Pienso en el pasaje de "El otro" (Borges, El libro de arena, Buenos Aires, 1975, p. 18) en que el Borges viejo le recita "lentamente" al Borges joven el verso de Victor Hugo L'hydreunivers tordant son corps écaillé d'astres, y el Borges joven, atónito, lo repite "en voz baja, saboreando cada resplandeciente palabra”. Y me pregunto: ¿habrá leído Hugo a Góngora? 
Jammes — "telar turquesco" como aposición de "Sidón"— deja entender que, para Góngora, la fenicia Sidón era ciudad turca.

El adjetivo sidón no ofrece dificultad. Ya Leo Spitzer llamó la atención sobre el adjetivo latino sidonis (documentado sólo en femenino, pero eso no importa). Góngora podía elegir entre dos gentilicios de Sidón: sidonios y sidones; y la prueba está en dos alusiones suyas a la casa de Medina Sidonia: "sidonios muros" (Panegírico, v. 119) y "los clarísimos Sidones" (silva "Generoso mancebo...", v. 61). Por otra parte, en esos tiempos no se hablaba de los japoneses, sino de los japones. Un caso parecido es el de bengala I: 667, comentado así por Jammes: "Tiene que ser metonimia (un poco forzada, hay que reconocerlo), por bengali’. Pero ¿por qué metonimia forzada, si también Manuel Ponce habla con toda naturalidad de "los etíopes bengalas"? (El gentilicio bengali se forjó tardíamente.)

I: 653.] tanta acusa tea. “iLindo decir!”, se mofa escuetamente Jáuregui; y Salcedo amplía la censura: "figura viciosísima, que se llama cacofatón". Jammes supone que "lo diría por la aliteración $t$, $t, t$ ". También puede suponerse que, para él, las dos últimas palabras se prestaban a ser leídas como una sola, acusatea, cacofónica, grotesca, no por su significado (pues no significa nada), sino por su sonido. Es una crítica exactamente análoga a la que Jáuregui y Salcedo hacen de "que impide Amor que aun otro chopo lea" (I: 700): "aquellas dos dicciones, chopo y lea", dice Salcedo, hacen "mala consonancia": suenan mal estando juntas; invitan a leer chopolea; y Jáuregui, con su habitual énfasis: "Por sólo no decir chopolea, había V.m. de callar todos los días de su vida". También es cacofatón, dice Salcedo, el "can de lanas prolijo" de II: 799, "porque, juntándose las dicciones, hacen una de mal sonido, que es candelanas" ("No hubiera sido más severo Jáuregui", comenta Jam-

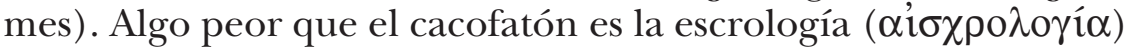
que el Abad de Rute encuentra en el conculcado de I: 415, reprobadísimo por él evidentemente porque, al leerlo, de manera espontánea e irresistible su imaginación le representaba una palabra "de sucio significado en el sonido": ;culo!

I: 797.] flechen mosquetas, nieven azahares. Según Jammes, Góngora dice flechen "porque la mosqueta... tiene espinas". A mí no me convence esa ecuación espinas = flechas. No creo que venga al caso. Lo que Góngora dice es que parece caer una nevada, pero son azahares; parece caer una lluvia de flechas, pero son mosquetas. La 
ecuación va por otro lado. La mosqueta, como oportunamente explica Jammes, es una "rosa pequeña muy olorosa". ¿Y qué son los azahares sino flores pequeñas muy olorosas? En la aromática y leve lluvia no tienen nada que hacer las espinas de la mosqueta, aparte de que unas y otras flores irían desprendidas de su tallo.

I: 813.] en lunas desiguales. "Los comentaristas antiguos no parecen haber entendido este pasaje", dice Jammes, el cual le da una explicación muy persuasiva. No sería ocioso remitir a los desiguales días de I: 906. Y cf. también II: 409, "a cada conjunción su pesquería".

I: 838.] de Aracnes otras la arrogancia vana. Yo creo que no está bien hablar de "genitivo" a propósito de la forma Aracnes. Lo normal sería Aracne, desde luego, pero Aracnes está "en serie" con formas no raras en tiempos de Góngora (y debidas quizá a influencia de $C e$ res o Cibeles): Dafnes 'Dafne', Procnes 'Procne', Salmaces 'Sálmacis', y con mucha frecuencia Psiques (cf. la "villana Psiques" de I: 774, que Jammes, en su prosificación, debió tal vez haber cambiado en Psique, tal como cambia Aracnes en Aracne). Otro caso: la Filódoces 'Filódoce' de II: 448.

I: 866.] Manjares que el veneno / y el apetito ignoran igualmente. Según Jammes, aquí apetito es dignificación de una "voz familiar y jocosa", apetite, que significa 'sainete, salsa, gustillo para gustar y apetecer alguna cosa'. Pero no creo que Góngora haya querido decir que los manjares del banquete serrano - banquete de bodas además, esmeradamente dispuesto- carecieran de algo tan natural y tan bueno como el "gustillo" de una sabrosa salsita. Yo sugeriría simplemente poner en apetito cierto énfasis semántico (en correspondencia con el énfasis de veneno): de la misma manera que aquí se desconoce el veneno, se desconoce el refinamiento culinario, el sibaritismo gastronómico de los grandes señores, igual al de los Césares de la decadencia.

I: 890.] entró bailando numerosamente. En la lengua normal, numeroso hace referencia a 'número' (por ejemplo, "concurso numeroso"), mientras que en la de Góngora se refiere por regla general a 'armonía', 'cadencia' o 'musicalidad', de tal manera que una referencia a verdadero 'número' casi podría considerarse como segundo sentido, o sentido figurado. Claro que en este verso el sentido primario de numerosamente es 'cadenciosamente', pero, ha- 
biendo dicho Góngora con dos expresiones numéricas cuántas eran las bailadoras, primero $6+6$ y luego $3 \times 4$, no será absurdo pensar que en el numerosamente metió una alusión a esos números. Sería un chiste muy parecido al que Jammes observa en II: 181: los dulces números del peregrino, su dulce canción, son números "reales" para el Océano ${ }^{36}$.

I: 896.] siempre vivid esposos. Así imprime Jammes, sin la coma que D. Alonso pone después de vivid; y explica: 'vivid siempre como prometidos, como enamorados', aduciendo a Covarrubias, según el cual esposa y esposo son (etimológicamente) "los que se han dado palabra de casamiento". Puede ser que Góngora diga esposos en ese sentido ('que el tierno amor que hoy os tenéis dure siempre'). Pero como esposo y esposa también significaban 'marido' y 'mujer' (cf., sin ir más lejos, el esposo de I: 154), igual puede haber pensado en la armonía conyugal de quienes van a quedar unidos para toda la vida. La coma de D. Alonso podría estar bien.

I: 943.] que en letras pocas lean muchos años. Jammes cita aquí a A. Carreira: "Porque las décadas novena y décima son las que, en numeración romana, requieren menos letras, dentro del límite normal de la vida". Esta "explicación ingeniosa" le gusta mucho a Jammes: "quizás se haya de preferir", dice, a la que él mismo da: "En letras pocas, porque la vida de una pareja feliz se puede resumir en poquísimas palabras". Para mí, en cambio, no sólo es esta última la que hay que preferir, sino que es la única buena. En el cementerio de una aldea no hay largos y pomposos epitafios, sino lápidas modestas. La interpretación de Carreira cojea por varios lados: en la numeración romana las décadas novena y décima (XC y $\mathrm{C}$ ) requieren el mismo número de letras que la cuarta y la quinta (XL y L); además, esos números romanos estarán bien en los epitafios suntuosos, no en las lápidas pueblerinas; y no puede decirse -muchísimo menos si se piensa en los tiempos de Góngora-que la edad de 90 o 100 años sea el límite "normal" de la vida.

I: 953.] el rey... de los otros ríos. Cita Jammes la curiosa crítica de Jáuregui: que, en la lengua poética consagrada, el rey de los otros ríos

36 Cf. también la nota sobre "número crece y multiplica voces" (I: 232). Son muy de agradecer las notas en que Jammes llama la atención sobre la frecuente irrupción del chiste, la travesura, la ironía, la connotación humorística. Por ejemplo, las notas a Sol. I, 121, 295, 334, 594 y 849, y a Sol. II, 262, 460, 678, 732, 760 y 943 . 
es el Po, no el Nilo, como aquí dice Góngora. No estaría de más recordar el soneto "Rey de los otros, río caudaloso...", donde el rey es el Guadalquivir.

I: 973.] mañosos, al fin, hijos de la tierra. Yo creo que es mejor suprimir la coma de al fin; queda así más clara la comparación de los robustos luchadores campesinos (hijos de la tierra) con Anteo, el mítico Gigante ('hijo de Gea') que al luchar con Hércules recobraba todas sus fuerzas cada vez que hacía contacto con la madre Tierra. Lo que Góngora dice es: 'mañosos, auténticos hijos de la Tierra como son', etc.; no serán unos Alcides, pero sí unos Anteos. La forma de este comentario se parece a la del que hace Góngora sobre los "oblicuos engaños" del neblí: "griego al fin" (II: 915); igriego tenía que ser!

I: 1012.] Si no tan corpulento, más adusto. A este adusto le dedica Jammes una larga nota (que continúa en el apéndice, pp. 602-603). ¡Cuánta tinta gastaron los comentaristas antiguos en su explicación! ¡Y qué conflicto de opiniones! Con razón dice Jammes al final: "Uno tiene a veces... la impresión de que los gongoristas del siglo XvII no hablaban todos la misma lengua". Una cosa es clara: que - a diferencia de lo que ocurre en I: 668-, en este adusto no hay referencia a color (moreno), tal como no la hay por ejemplo en "rostro adusto". La interpretación de Jammes, 'enjuto de carnes' (como la de D. Alonso, 'cenceño, recio y curtido') es, desde luego, la correcta. (Un ager adustus es un campo requemado por el sol, o sea 'reseco'.) Se puede añadir que Góngora mismo se encarga de explicar abundantemente el adusto al comparar a su serrano con el ayuno leopardo (onza, guepardo, gattopardo, cheetah), con el corcillo travieso y con el muflón sardo ${ }^{37}$ : tres animales esbeltos, acerados, agilísimos, todos músculo y nervio.

I: 1049.] los hercúleos troncos. Es "curioso" en efecto, como dice Jammes, que aquí y en I: 829 los árboles de Hércules/Alcides sean los olmos y no los álamos. Pero, como dice también, "no es imposible que la confusión sea de origen popular", y cita la observación (recogida por Corominas) de que "en Andalucía las alamedas son de

37 A lo que dice Pellicer sobre el muflón podría añadirse lo que dice Covarrubias, s.v. cuerno: "A las rupicapras, por otro nombre íbyces, les sirven los cuernos [no un cuerno, como dice Pellicer] de recogerse dentro dellos [?] y dexarse despeñar de los riscos quando se veen perseguidas de los perros, y con esto no reciben daño, porque les sirven de caxa y reparo". 
olmos". Yo he observado que en México, donde abundan los álamos y escasean los olmos, hay quienes llaman olmos a los álamos. ¿Confusión "andalucista”? ¿Simple semejanza de las palabras álamo y olmo?

II: 27.] En la incierta ribera, / guarnición desigual a tanto espejo. Después de observar que "Salcedo reúne estos dos versos a la frase que precede, mientras que Pellicer los considera principio de la frase siguiente", dice Jammes que se podría "vacilar entre las dos construcciones". Yo de ninguna manera vacilo: la construcción de Pellicer (y de D. Alonso, y de Jammes) tiene que ser la buena. Hay claramente un "punto y aparte" en el v. 26, y el relato continúa: 'El Alba sorprendió al peregrino en esa incierta ribera que he descrito', etcétera.

II: 78.] Dédalo, si de leño no, de lino. A propósito de "o el Austro brame o la arboleda cruja" (I: 83) ha observado Jammes: "Aliteración expresiva y visiblemente intencionada". Una observación análoga no estaría de más a propósito de este otro verso, que es todo aliteración pura. Mi experiencia de profesor me enseña que los lectores, atentos al sentido, suelen no parar mientes en las "figuras de sonido", aliteración, paronomasia, etc. En I: 605 , la doble paronomasia galeras/grullas y volantes/veleras pone de relieve la ecuación grullas $=$ naves .

II: 89.] Dice Jammes que hay "anacoluto al final [de este verso]". Yo no creo que se trate propiamente de anacoluto. El significado de "aquella que... una venera fue su cuna" es, desde luego, 'aquella cuya cuna fue una venera' (o sea Venus). Lo que yo observaría es que este que su $-\mathrm{o}$ que tu, etc.- en vez de cuyo es un giro sumamente peculiar de Góngora: "[Oh Guadalquivir,] que... / tosca guirnalda de robusto pino / ciñe $t u$ frente", o sea "cuya frente...' (Millé 226, de 1582); "Levantas el arco... / contra los que sus juicios...”, o sea 'contra aquellos cuyos juicios...' (Millé 8, de 1585?); "Trescientos Cenetes... / que los rayos de la luna / descubrieron sus adargas" (Millé 23, de 1587); "las rosas que la muerte / va violando sus colores" (Millé 48, de 1602); "la Fénix que ayer Lerma fue su Arabia” (Millé 270, de 1603); "del Fénix hoy que reinos son sus plumas" (Millé 284, de 1606); "Pastor que una Granada es vuestra choza" (Millé 313, de 1611); "el grano... que / su tierra una Virgen fue" (Millé 183, de 1621); "blanco toro / que ignore el yugo su lozano cuello" (Millé 361, también de 1621). Y en las So- 
ledades: "ni la que su alimento / el áspid es gitano" (I: 110); "El promontorio que Éolo sus rocas / candados hizo...", etc. (I: 447); "las volantes pías / que azules ojos... / sus plumas son" (I: 807); "Corderillos... / que... / las perlas exceda del rocío / su número" (I: 914); "a la [cabra] que... / flores su cuerno es, rayos su pelo" (II: 306); "el neblí, que... / su ignorado nido...", etc. (II: 745) ${ }^{38}$.

II: 114.] los extremos / deste métrico llanto. Dice Jammes que extremo es "palabra ambigua", y, tras citar la explicación de Salcedo y la traducción de D. Alonso, concluye: "Confieso mi perplejidad". Yo no veo ningún motivo de perplejidad: "hacer extremos", como dice Covarrubias s.v. estremo, es hacer demostraciones enfáticas de un sentimiento apasionado. De hecho, la interpretación de Alonso no contradice a la de Salcedo, pero la de éste es más abarcadora: los extremos se refieren al fondo y también a la forma; si extremado es el doloroso sentir del peregrino, extremado es asimismo el artificio de su "métrico llanto": ocho estancias en que se observan rigurosamente las reglas de la canzone, con una exquisitez más: el primer verso rima en cada estancia con los dos últimos ${ }^{39}$.

II: 156.] cansada / lágrima antes enjuta que llorada. Las lágrimas cansadas, dice Jammes, son "bordoncillo frecuente en la poesía amorosa del siglo xvI". No creo que sea muy frecuente, pero en todo caso, y en vista de los únicos ejemplos que cita Jammes, es muy claro que la expresión era predilecta de Góngora ${ }^{40}$. En general, el

38 También en I: 215 habla Jammes de "anacoluto". El pasaje dice: "aquellas que los árboles apenas / dejan ser torres hoy..., / las estrellas nocturnas luminarias / eran de sus almenas". Es un giro no idéntico, pero sí parecido al que aquí comento. Cf. también "albergue pobre / que... / bóvedas lo coronan de espadañas" (II: 111) y "marino dios que, el vulto feroz hombre, / corvo es delfín la cola" (II: 463).

${ }^{39}$ Se puede observar que en "los extremos deste métrico llanto" está expresando Góngora su autoconsciencia poética. Hay aquí un mensaje que dice: 'El lector verá hasta dónde me he esmerado, hasta dónde me he pulido'. Cf. el pasaje del Quijote, I, 27, en que el Cura y el Barbero oyen en plena sierra una voz que "dulce y regaladamente sonaba”. ¡Extraña cosa! "Porque aunque suele decirse que por las selvas y campos se hallan pastores de voces estremadas, más son encarecimientos de poetas que verdades". Y cuando escuchan la refinada canción de Cardenio: “¿Quién menoscaba mis bienes? —Desdenes”, su admiración sube de punto, pues "lo que oían cantar eran versos no de rústicos ganaderos, sino de discretos cortesanos". También Cervantes se elogia; su autoconsciencia artística es tan fuerte como la de Góngora. Cf. las primeras páginas de mi artículo "Perduración del ovillejo cervantino", NRFH, 38 (1990), 643 ss.

${ }^{40} \mathrm{El}$ tema del llanto interminable venía de Garcisánchez ("Lágrimas de mi 
sentido es 'lágrimas salidas de ojos cansados de tanto llorar', pero en este verso II: 156 "el sentido es diferente y casi opuesto, ya que se trata de una lagrimilla tan poco sincera que tarda en salir, como si estuviera cansada”. ¡Exacto! O sea que Góngora le da otra vida a su propio bordoncillo, tal como da vida nueva a tantos "préstamos" de otros poetas.

II: 321.] (aljófar vomitando fugitivo / en lugar de veneno). Yo creo que no hay que poner entre paréntesis estos versos, pues lo que dicen es parte integrante, y muy significativa, de la oración principal: la fuente se desliza como sierpe; es una sierpe, y he aquí que el pie grosero de un pino la está pisando; la sierpe metafórica hace entonces lo que las sierpes reales: vomita el "veneno" que puede. (Es un caso parecido al de I: 233.)

II: 342.] duro alimento, pero sueño blando. Sí, las bellotas son duras para los dientes, pero el corcho ofrece un sueño blando. "Sólo falta saber ahora - dice curiosamente Jammes- cómo se hacían exactamente esas camas primitivas [las de la Edad de Oro]: ¿rellenando un colchón con trocitos menudos de corcho?” Por supuesto que no, pues en primer lugar los colchones no van bien con el candor de la Edad primera. Las “camas primitivas” serían grandes láminas o lonjas arrancadas sin más del tronco del alcornoque.

II: 451.] el cabello en estambre azul cogido, / celoso alcaide de sus trenzas de oro. El adjetivo celoso, según Salcedo, puede implicar una comparación de la redecilla de estambre con el enrejado de una celosía, o bien puede ser alusión al color. Jammes se limita a decir que Salcedo escoge lo segundo. En realidad, la disyuntiva no tiene razón de ser: la red es un alcaide que tiene encarcelado al par de trenzas de oro, y su color demuestra que lo hace por celos. No estaría de más una nota sobre el color azul como símbolo de los celos. (Cf. "Las flores del romero, / niña Isabel...".)

consuelo..., / salid, salid sin recelo, / y regad estas mejillas / que soléis") y de Garcilaso ("Salid sin duelo, lágrimas, corriendo"); pero Carvajal y Robles estaba copiando seguramente a Góngora en el comienzo de su soneto "Salid, cansadas lágrimas, huyendo..." (Flores de Calderón [1611], ed. F. Rodríguez Marín, Sevilla, 1896, p. 173). Un caso parecido es el del soneto de Luis Martín (ibid., p. 123): "Subido en la mitad del cielo ardía, / usando de su oficio generoso, / el rey desotros astros luminoso...", obvia imitación de Góngora: “...y usando, al esparcir tu nueva lumbre, / tu generoso oficio y real costumbre" (soneto "Raya, dorado Sol..."). 
II: 464.] marino dios que, el vulto feroz hombre... Jammes interpreta feroz como epíteto de vulto, y dice que A. Carreira lo siente, en cambio, como epíteto de hombre. Tal vez la diferencia se quiebre de delgada, pero la traducción de Jammes, "siendo hombre por su cara feroz", da a entender que la ferocidad es rasgo característico del rostro humano, mientras que la interpretación de Carreira es muy lógica (y acorde con las representaciones pictóricas y escultóricas del Barroco): un Tritón tiene cola de delfín y rostro de hombre, pero de hombre salvaje (de "sátiro").

II: 488.] Onda pues sobre onda levantada. Jammes considera esta frase como un ablativo absoluto: 'habiendo levantado olas sobre olas', etc.; pero dice que hay otra construcción posible, en que la primera onda sería metáfora de fiera. Para mí, esta segunda construcción es a todas luces la buena: la fiera (el monstruoso pez herido) da un salto en el aire, sobre las olas; es ella misma una ola sobre las olas. Imagen exactamente análoga a la de II: 443: "las peñas embistió, peña escamada”.

II: 517.] dulcísimas querellas / de pescadores dos..., o sea el canto amebeo que comenzará veinticinco versos después, y que Jammes califica de "égloga piscatoria absolutamente perfecta". Se puede añadir que Góngora sabía muy bien lo que había hecho. Dice "dulcísimas querellas" — o, con lítotes, "números no rudos" (536)—, tal como ha dicho "los extremos / deste métrico llanto" (cf. supra, nota 39). Así como se extrema aquí en la finura de los versos, así también se extrema en la ponderación de su belleza. El canto va precedido de dos grandes elogios: 1) entre los cisnes del Caístro y del Meandro jamás se escucharon tan dulces quejas (523-526); y 2) el canto de los pescadores atrae irresistiblemente a un tropel de delfines, famosos connoisseurs de música (534-535). Y, terminado el canto, hay otros dos elogios: 1) las constelaciones del cielo estuvieron a punto de bajar desde la altura para oír mejor lo que cantaban los mancebos (612-625), y 2) si hasta los escollos absorbieron el melódico néctar, bien podemos imaginar lo que ocurrió en el pecho de ese oyente tan privilegiado, tan "predispuesto" 41 , que es el peregrino. (Cf. infra mi nota a II: 634.) En el canto de Líci-

${ }^{41}$ Cf., en el soneto "Cual parece al romper de la mañana...", el efecto de las lágrimas y el ardiente suspiro de la pastora: hasta las piedras podrían ablandarse; y "si enternecer bastara un duro canto, / mirad qué habrá con un corazón hecho, / que al llanto y al suspiro fue de cera”. 
das y Micón, dice Jammes, "Góngora aventaja a todos sus modelos antiguos y modernos: Teócrito, Virgilio, o Garcilaso". Y Góngora lo sabía. En la ponderación de su arte puso el mismo entusiasmo que en la ponderación del mundo natural.

II: 538.] de la culta Leusipe. La ortografía "culta" es sin duda Leucipe, pero Góngora — dice Jammes- "pronunciaría Leusipe, a la andaluza”. Seguramente sí, pero se trata aquí de un lenguaje escrito. Yo le doy la razón a $\mathrm{D}$. Alonso, que imprime Leucipe.

II: 565.] un Neptuno y otro: el Atlántico y el Pacífico, según Pellicer; pero Jammes prefiere la explicación de Salcedo: "ambos mares, esto es, el Océano [Atlántico] y el Mediterráneo”. En su apoyo podría mencionarse el soneto "No en bronces..." (al Marqués de Santa Cruz): "El un mar [el Atlántico] de tus velas coronado, / de tus remos el otro [el Mediterráneo] encanecido".

II: 604.] al tramontar del Sol mal solicita / abeja aun negligente flor marchita. Jammes glosa así: "cuando empieza a ponerse el sol, las abejas, aun las que salieron tarde, no suelen libar las flores marchitas". Yo creo que el tramontar del Sol no indica la hora en que alguna abeja muy perezosa sale por fin a cumplir su obligación, sino la hora en que las flores han perdido su lozanía. En esos momentos, hasta las abejas menos cuidadosas, menos atentas a su tarea, desdeñan las flores marchitas.

II: 612.] Invidia convocaba, si no celo... Jammes traduce celo por 'emulación'. Yo creo que una traducción más precisa sería 'celos' (entre emulación y envidia no hay mucha diferencia). Se conocen casos de celo en el sentido de 'celos': véase mi art. cit. de NRFH, 36 (1988), p. 968, nota 26.

II: 621.] el piscatorio cántico impedido. La versión de Jammes dice: "Como el ruido [de] la sonante esfera... impedía que las dos Osas... oyeran el canto de los pescadores, hubieran bajado...", etc. Hay cierta falta de lógica, pues si las Osas no estaban oyendo el canto, no había por qué les entrara el deseo de bajar. (Encuentro el mismo non sequitur en la versión de D. Alonso.) Creo que hay que dar a impedir el significado gongorino "normal", o sea 'estorbar': el canto de los pescadores les llega a las Osas con mucha "estática", entremezclado con el ruido de la máquina cósmica, y quisieran bajar para oír mejor. 
II: 634.] que dictaba los números que oía. ¿Cuál es el sujeto de oía? Sin duda D. Alonso "complica mucho la frase" al suponer (con Pellicer) que el sujeto es el propio Amor que dictaba los "números". El sujeto, dice Jammes, "puede ser la virginal copia [la pareja de hermanas, Leucipe y Cloris] o el peregrino". (Pero no se decide por lo uno o lo otro, pues en su traducción dice "los versos que oían".) Para mí es evidente que el sujeto es el peregrino. El pasaje todo (626634) habla del efecto que en él produjo el canto de los pescadores: ¿cómo no iba a llegarle al alma, si hasta los escollos se conmovieron, y si quien inspiró esos versos que él oía fue el ciego ingenioso, el dios Amor?

II: 698.] mármol, al fin, tan por lo pario puro... No estaría de más una mención de M. R. Lida, Juan de Mena, poeta del Prerrenacimiento español, El Colegio de México, 1950, pp. 370-372.

II: 726.] cuy a fecunda madre... Dice Jammes: "Queda sin verbo principal el sujeto (fecunda madre)... y es sustituido en el v. siguiente por otro sujeto (Guadalete) ..., ruptura de construcción [que] hace particularmente ardua la versión en prosa”. Yo creo que hay una manera muy simple de resolver la dificultad. Pongamos entre paréntesis los vv. 726-728, omitámoslos de momento, y leamos: "Al Sol levantó apenas la ancha frente / el veloz hijo ardiente / del Céfiro lascivo, / que ['cuando'] a mucho humo abriendo / la fogosa nariz...", etc. (la secuencia entre los vv. 725 y 729 es perfecta). La frase entre paréntesis, completa en sí misma, con ablativo absoluto al comienzo, se refiere a la crianza del potro andaluz: la yegua madre le vistió miembros (cf. Millé 74, v. 93: "que viendo quien la vistió...", etc.), y el Guadalete le dio "florida ambrosia" como pasto.

II: 735.] Entre el confuso, pues, celoso estruendo... Dice Jammes que celoso alude a la rivalidad entre los caballos de Apolo y los del Conde de Niebla (a sus celos mutuos: cf. supra, nota a II: 612). Sí, y también confuso: en la sinfonía de relinchos rivales son indistinguibles, de tan mezclados, los instrumentos que componen la grandiosa fanfarria.

II: 754.] el Girifalte..., / honor robusto de Gelanda. Los gerifaltes, observa Jammes, proceden de las zonas nórdicas de Europa y América, "y no sólo de Zelanda". También D. Alonso "traduce" Gelan$d a$ por 'Zelanda'. Pero Zelanda o Zelandia es una provincia de 
Holanda muy al ras del mar (Zeeland en holandés), difícilmente engendradora de gerifaltes. Podría pensarse que Góngora se refiere a Seelanda o Seelandia, la isla mayor de Dinamarca (Sjaelland en danés); pero me parece más verosímil que Gelanda sea adaptación — quizá ya existente en textos latinos del Renacimiento- de Island (Islandia), donde el escandinavo is 'hielo' se tradujo al latín gelu. Obsérvese que cuando Góngora vuelve a hablar del gerifalte, en II: 906, lo llama "boreal harpía”.

II: 773.] Tú, infestador en nuestra Europa nuevo / de las aves..., Aleto. No hace Jammes ningún comentario, sino que se limita a reproducir el de Salcedo: "En el sexto lugar pone D. Luis al aleto, llamado de algunos halcón giboso". De donde se deduce que a ese pájaro llevado de América "algunos" lo llamaban halcón giboso, pero que su nombre verdadero, o el más conocido, era aleto. Esta voz, aleto, está (¿desde cuándo?) en el DRAE, que dice que es lo mismo que halieto; y s.v. halieto remite a águila pescadora, que es un

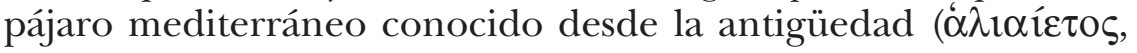
haliaeetus), o sea nada nuevo en "nuestra Europa", y además "infestador" de peces, no de aves. Yo estoy seguro de que el nombre aleto no existió nunca: el Aleto de Góngora no puede ser sino Alecto, una de las tres Furias. El pájaro americano es una Furia, tal como el gerifalte es una Harpía.

II: 829.] más sabandijas de cristal que a Egipto... "Bellísima imagen", dice Jammes. Y muy enfática, en vista de la inmensa superficie cubierta por las inundaciones del Nilo. Con la misma hipérbole (pero sin lirismo alguno) describe Góngora, en carta de 1614 (Jammes, p. 630), el Nilo de censuras y repudios que se ha precipitado sobre el Polifemo y las Soledades: "tanto crítico, tanto pedante como ha dejado la inundación gramática en este Egipto moderno”. (Y ojalá no se aplique eso a mí.)

\section{APÉNDICE}

El soneto "Restituye a tu modo horror divino...", escrito en "verano u otoño de 1615" según Jammes (que le dedica las pp. 638642), es una respuesta altiva, aristocrática, a la "inundación gramática" desatada contra las Soledades desde el año anterior. En él subraya Góngora la identificación entre los "pasos" del peregrino y los "dulces versos" del poema. Como dice Jammes: "Desde el 
principio del soneto están presentes los dos sentidos de la palabra: Soledad-poema, soledad-campo", y la expresión "bosque incierto" (v. 10) puede asimismo ser "metáfora del poema: bosque porque es una silva, incierto porque no obedece a un esquema métrico riguroso". Y dice por otra parte algo que merece comentario: "Tanto en el primer cuarteto como en los dos tercetos, el poeta aconseja a la Soledad (poema) que vuelva a su soledad (campo, selvas), que se restituya a sí misma, a su silencio, huyendo del poblado (de la Corte) donde están los críticos". ¿Qué sucede entonces en el segundo cuarteto? En éste, según la interpretación de Salcedo, aceptada por Jammes, hay una ruptura, un salto de la segunda persona gramatical, "¡Oh amiga Soledad!", a la tercera: "Un prudente cónsul...", y el cónsul —o "jurisconsulto", como traduce Jammes con cierta libertad - resulta ser Francisco de Amaya, amigo de Góngora, que en la tranquilidad de su casa de Antequera se dedica a leer y entender las Soledades. Pero yo estoy convencido de que la interpretación de Salcedo (su conjetura, mejor dicho) es errónea. A mí me parece que el segundo cuarteto es continuación perfecta del primero; que también en el segundo cuarteto "aconseja" Góngora a su poema que vuelva a su soledad.

"Prudente Cónsul, de las selvas digno, / ...busca... / tu claustro verde", dice ese segundo cuarteto. Y creo que el Cónsul no ha sido identificado satisfactoriamente. Dice muy bien Jammes que el personaje a quien Góngora se refiere es, "al revés del de Virgilio", un Cónsul digno de las selvas. Salta a la vista, en efecto, la alusión a Virgilio, que comienza la Bucólica IV expresando el deseo de que las selvas sean dignas de un Cónsul ("si canimus silvas, silvae sint consule dignae"). El escribió esta Bucólica en homenaje al cónsul Asinio Polión, amigo suyo y lector de sus poesías pastoriles ("Pollio amat nostram, quamvis est rustica, Musam", Buc. III, 84). En honor de él es preciso que las Musas Sicélides, las inspiradoras de Teócrito, canten "cosas más grandes" que las acostumbradas. Por eso en la Bucólica $I V$ no hay pastores: Virgilio hace que las Musas silvestres, dejando prados y arroyos, se trasladen a "la Corte" y canten para oídos muy refinados. En el soneto de Góngora el movimiento es al revés: huida del mundo cortesano y regreso al mundo silvestre.

Este regreso al mundo silvestre es lo que inmortalizó a otro Cónsul, el semilegendario Cincinnato, que, nombrado dictador por seis meses, llevó a cabo rápidamente lo que de él se esperaba, y a los dieciséis días renunció a la dictadura para volver a su amado "claustro verde" (el campo que él cultivaba con sus propias ma- 
nos). Cincinnato y Catón son los dos supremos paradigmas de la virtus romana. A mí no me cabe duda: es Cincinnato el "prudente Cónsul" cuya conducta deben imitar las Soledades. La invitación del primer cuarteto - ‘'Regresa a tu soledad, oh amiga Soledad!' - se refuerza en el segundo con el ilustre exemplum: 'Sé un Cincinnato que, desatado de impedimentos, toma la prudente decisión de volver a su amado retiro'. El imperativo restituye del primer cuarteto está en serie con el busca del segundo, y " $t u$ mudo horror divino" 42 en serie con "tu claustro verde".

La fusión de Polión y Cincinnato es, para mí, uno de esos casos de alusión compleja que, como excelentemente lo hace ver Jammes en no pocas notas, es característica esencial del estilo de Góngora. Y, además, esta alusión compleja le "restituye" al soneto su impecable unidad.

En la descripción de la Corte que hizo Góngora en 1606 ("Musas, si la pluma mía...") estaba ya el tema, pero "al revés": en la Corte las Musas silvestres se hacen cortesanas; aquí todo está transmutado; hay que ver en qué paran las Didos y las Lucrecias; en la Corte, "el más rígido Catón / brujulea a una chacona", y "de las selvas cansados / los Cónsules están ya": Cincinnato cambia el silencio y la paz por el ruido y la agitación. (En un contexto análogo aparecen Catón y Lucrecia en la Sol. I, 498.) Por lo demás, el "desengaño" que se expresa en el soneto "Restituye a tu mudo horror divino..." es análogo al de los tercetos de 1609, “¡Mal haya el que en señores idolatra...!", donde Góngora repudia la vida cortesana y anuncia su regreso a la paz de su huerta cordobesa (";OH Soledad, de la quietud divina / dulce prenda...!").

Antonio Alatorre El Colegio de México

42 Los aspectos brutos y sombríos de la soledad-paisaje son parte integrante de su hechizo. Al final del romance "En un pastoral albergue...", al describir la dichosa soledad en que transcurren los amores de Angélica y Medoro, menciona Góngora los airecillos, los prados, etc., y no olvida las cuevas "con sus horrores". 